\title{
WestVirginiaUniversity
}

THE RESEARCH REPOSITORY @ WVU

Graduate Theses, Dissertations, and Problem Reports

2014

\section{Grazing Management Practices among West Virginia Beef Producers}

\author{
Marcus T. McCartney
}

Follow this and additional works at: https://researchrepository.wvu.edu/etd

\section{Recommended Citation}

McCartney, Marcus T., "Grazing Management Practices among West Virginia Beef Producers" (2014). Graduate Theses, Dissertations, and Problem Reports. 6189.

https://researchrepository.wvu.edu/etd/6189

This Thesis is protected by copyright and/or related rights. It has been brought to you by the The Research Repository @ WVU with permission from the rights-holder(s). You are free to use this Thesis in any way that is permitted by the copyright and related rights legislation that applies to your use. For other uses you must obtain permission from the rights-holder(s) directly, unless additional rights are indicated by a Creative Commons license in the record and/ or on the work itself. This Thesis has been accepted for inclusion in WVU Graduate Theses, Dissertations, and Problem Reports collection by an authorized administrator of The Research Repository @ WVU. For more information, please contact researchrepository@mail.wvu.edu. 
Grazing Management Practices among West Virginia Beef Producers

Marcus T. McCartney

Thesis submitted to the
Davis College of Agriculture, Natural Resource and Design
West Virginia University
in partial fulfillment of the requirements
for the degree of

Master of Science

in

Agricultural and Extension Education

Deborah A. Boone, Ph.D., Chair

Harry N. Boone, Jr., Ph.D.

Edward B. Rayburn, Ph.D.

Division of Resource Management

Morgantown, West Virginia

2014

Keywords: agriculture, intensive rotational grazing, sustainability, pasture, barriers, and best management practices 


\begin{abstract}
Grazing Management Practices among West Virginia Beef Producers
\end{abstract}

Marcus T. McCartney

The importance of sustainability has been recognized around the globe due to significant concerns about the unintended social, environmental, and economic effects of rapid population growth, economic growth and natural resource consumption and since has been implemented into government policies. Agriculture can significantly affect sustainability. It is vital to understand the current practices of farmers to promote best practices where needed and to continue to support and encourage best practices being utilized.

The purpose of this study was to determine the current grazing management practices among West Virginia beef producers. A descriptive research design using a mailed questionnaire was used to collect the data for this study. The target population was all beef producers in West Virginia. The study found that orchard grass was the most important grass species among West Virginia beef producers. Also, the study found the best management practices of soil testing occurs on three-fourth of the farms throughout West Virginia. However, some highly discouraged practices are also being used by producers; for example, unrestricted access to the streams - which often results in damage to stream banks and water quality. 


\section{DEDICATION}

This thesis is dedicated to my wife and best friend Kristin and to my precious children, Gavin and Morgan. 


\section{ACKNOWLEDGEMENTS}

Foremost, I would like to express my sincere gratitude to my advisor Dr. Deborah Boone for her continuous support of my graduate work and research. Her guidance has not only applied in academics, but also in life; for which I am truly and forever grateful.

In addition to my advisor, I would like to thank the rest of my thesis committee: Dr. Harry N. Boone and Dr. Edward B. Rayburn for their expertise, time, and insightful comments. Special thanks to Dr. Harry N. Boone for his assistance in data analysis.

I would like to thank all my friends who played a significant role in helping me to achieve my goals these last few years. I would like to extend a special acknowledgement to the following: Dr. Jim Gorman for mentoring, advising, and supporting me in my journey over the past few years, Hari Vommi for being an outstanding office mate and teacher in assisting me through the graduate process, and Dave Kesterson for his support and trust.

Finally, I would like to thank my family: my parents David and Teresa McCartney, my wife Kristin, my son Gavin, and my daughter Morgan for their support, consideration, patience, and devotion. I would like to my sister and her family for their encouragement, interest, and positive outlook. I would also like to thank my in-laws for supporting my family and myself during the many transition throughout our brief journey together as a family. Finally, special thanks to my wife who believes in me the same way I believe in her: unconditionally and never ending. 


\section{TABLE OF CONTENTS}

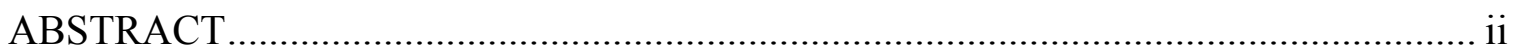

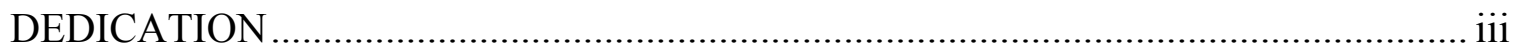

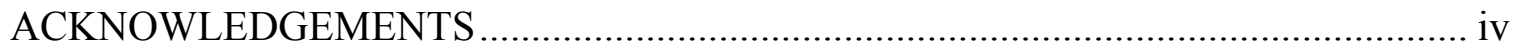

LIST OF TABLES ......................................................................................... viii

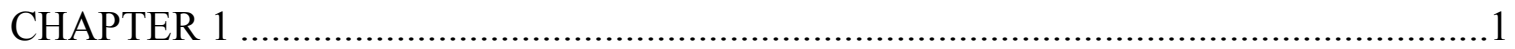

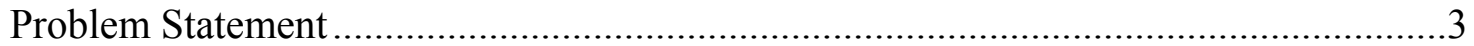

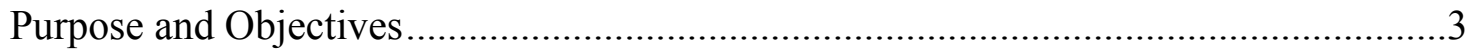

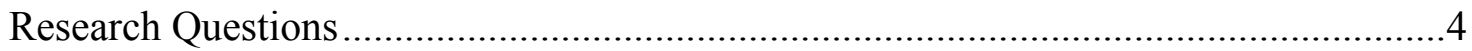



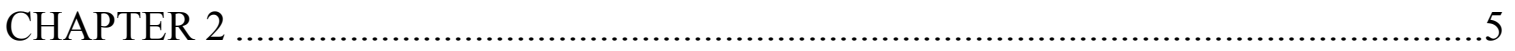

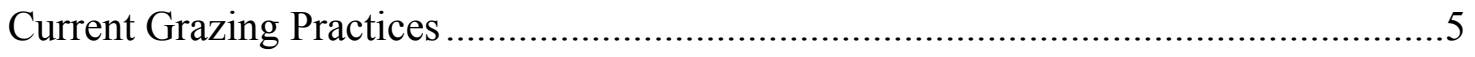

Barriers to Rotational Grazing ................................................................................

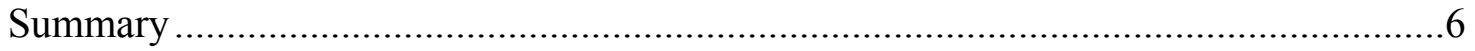

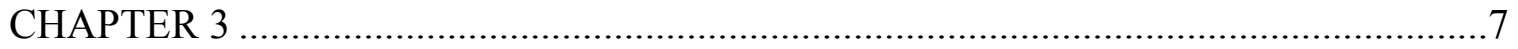

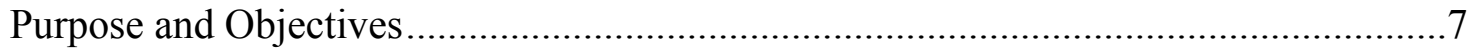

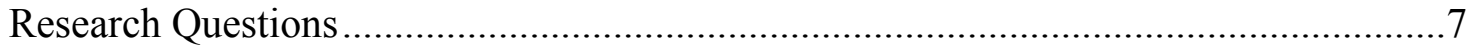

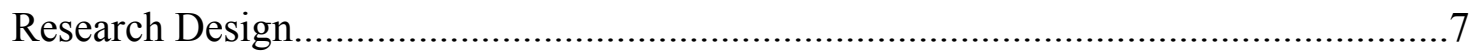

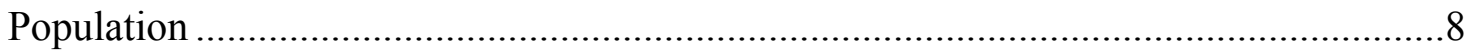

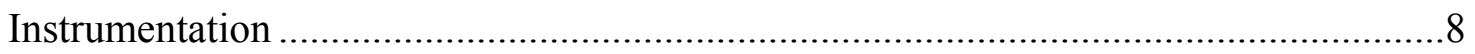

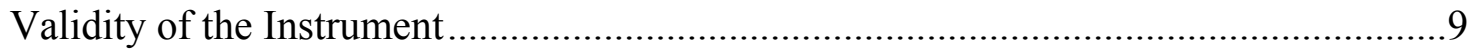



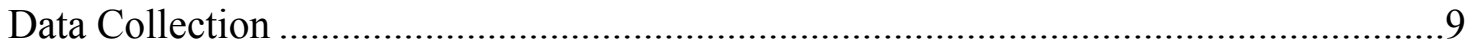

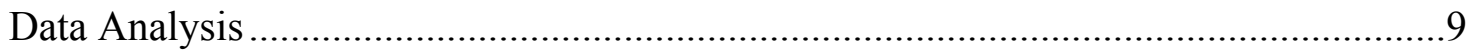

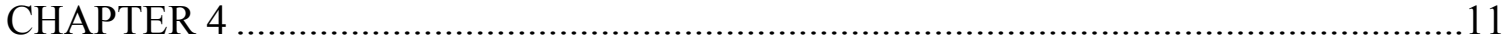


Purpose and Objectives...................................................................................11

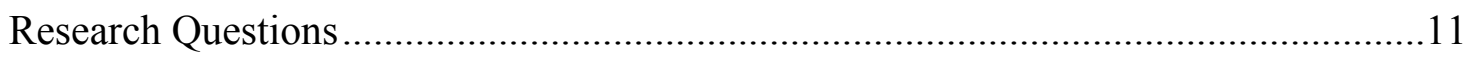

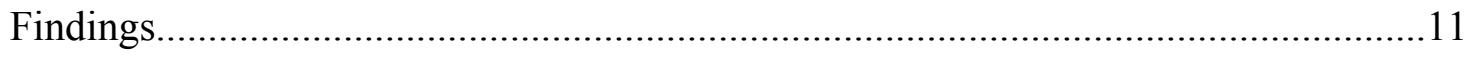

Conservation district represented by respondents.....................................................12

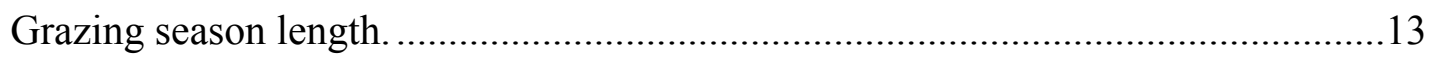

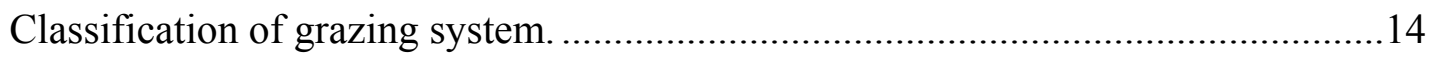

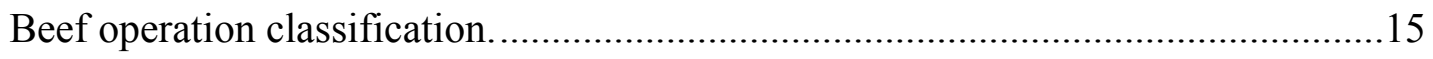

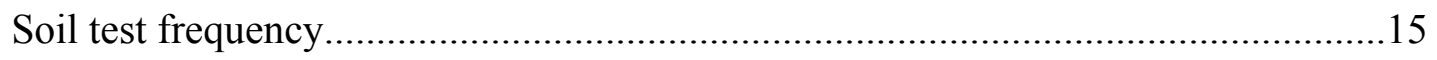

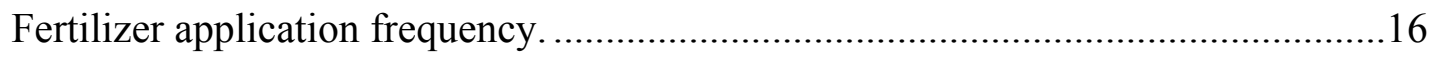

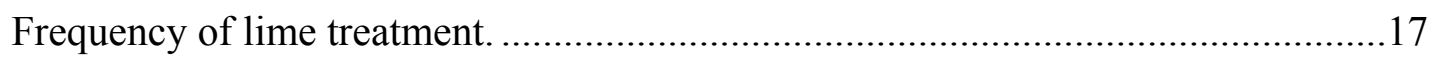

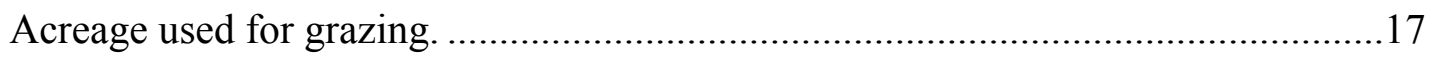

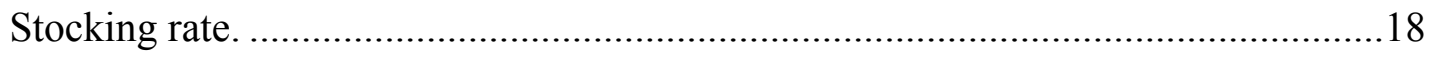

Importance of grass species in field composition...................................................19

Importance of legume species in field composition. ……………............................20

Extending grazing during the summer slump......................................................21

Extending grazing into winter and early spring....................................................22



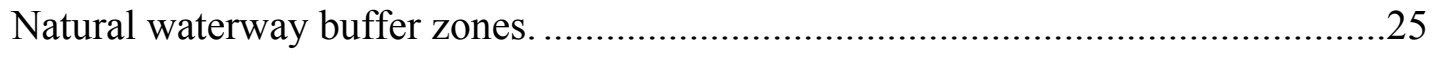

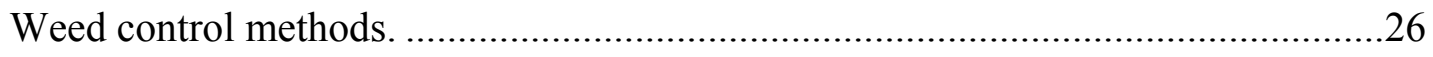

Barriers to rotational grazing as perceived from producers.....................................2

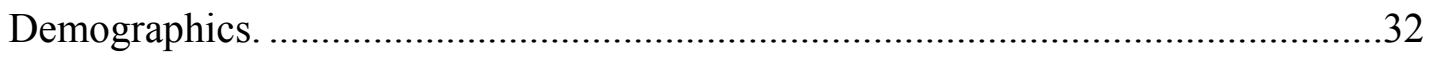

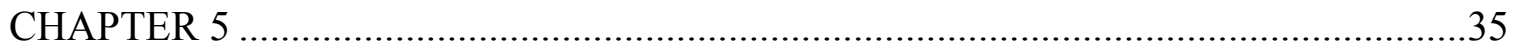

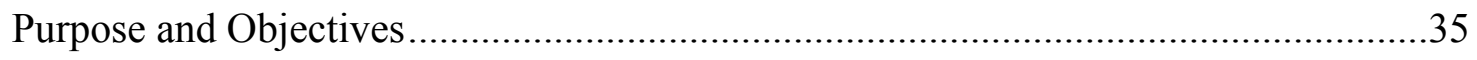

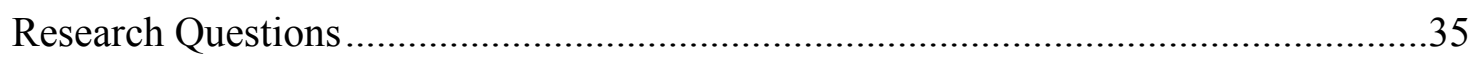

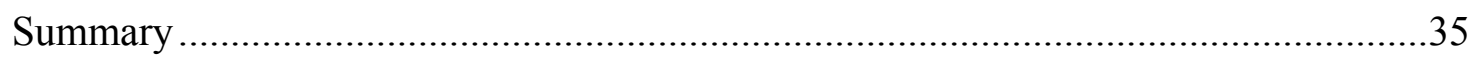




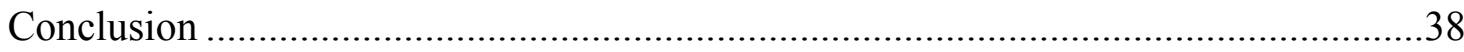

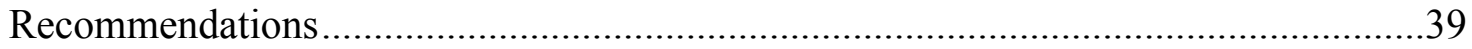

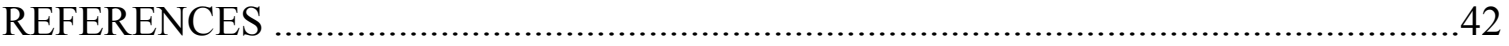

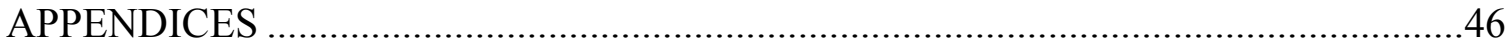

APPENDIX A: First Mailing Cover Letter .........................................................47

APPENDIX B: Second Mailing Cover Letter .......................................................49

APPENDIX C: Questionnaire..........................................................................51

APPENDIX D: Beef Producer Comments from Survey ........................................66

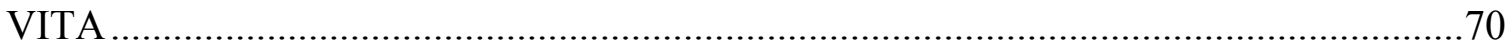




\section{LIST OF TABLES}

Table Title Page

1 Conservation District Represented by Respondents ........................................13

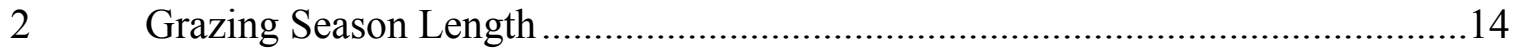

3 Classification of Grazing System on Farm ..................................................14

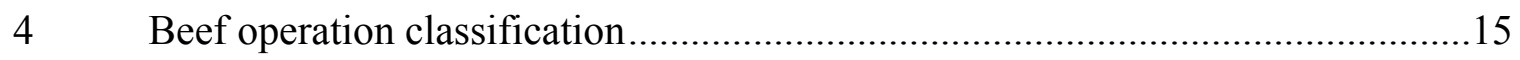

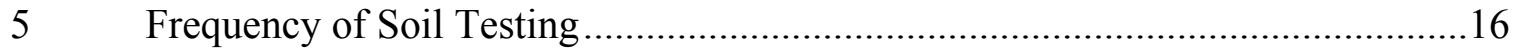

$6 \quad$ Frequency of Applying Fertilizer......................................................... 16

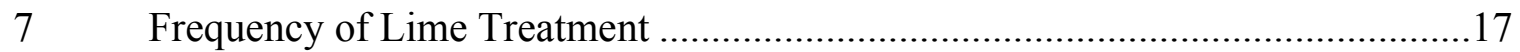

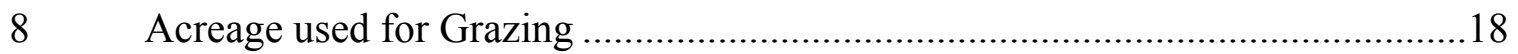

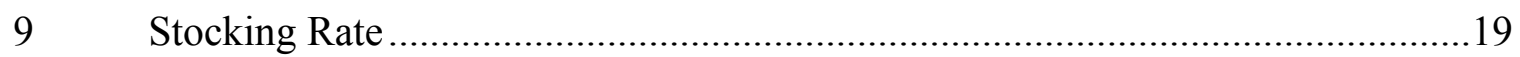

10 Importance of Grass Species in Field Composition.........................................20

11 Importance of Legume Species in Field Composition....................................21

12 Methods to Extend Grazing during the Summer Slump ...................................22

13 Methods for Extending Grazing into Winter and Early Spring .........................23

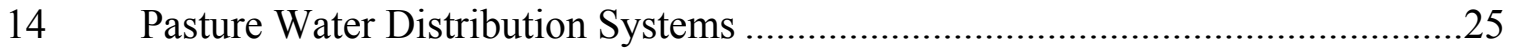

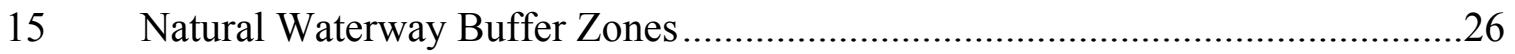

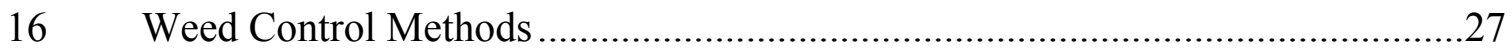

17 Barriers to Rotational Grazing as Perceived from Producers .............................30

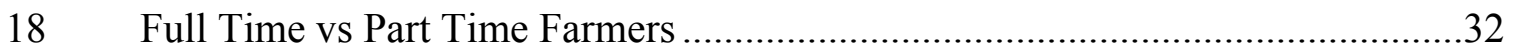

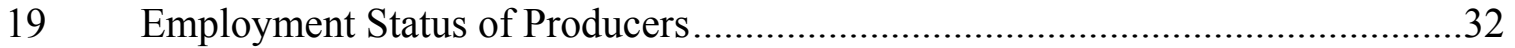



21 Producers' Highest Level of Education Completed.........................................34 


\section{CHAPTER 1}

\section{Introduction}

Webster's online dictionary (2014) defines sustainability as being sustainable; which is being capable to sustain or maintain. It can also be defined as taking what we need to live now, without compromising the ability of future generations to meet their needs (United Nations, 1987). The importance of sustainability has been recognized around the globe due to significant concerns about the unintended social, environmental, and economic effects of rapid population growth, economic growth and natural resource consumption (Sustainability - Basic Information, 2014) and since has been implemented into government policies (History of Sustainability, 2014).

The concept of sustainability was first implemented as governmental policy in the United States in 1969 under the National Environmental Policy Act (NEPA). Globally, sustainability first gained attention during the 1972 United Nations Conference on the Human Environment. In 1987 the World Commission on Environment and Development published "Our Common Future" report, which gained worldwide recognition. This report outlined "sustainable development" and defined it as development that meets the needs of the present without compromising the ability of future generations to meet their own needs (History of Sustainability, 2014). From this report, sustainability evolved into three categories: social, economic and environmental; which must be kept in harmony to achieve sustainability (Farrington \& Kuhlman, 2010).

Agriculture significantly impacts sustainability (Tilman, Cassman, Matson, Naylor, \& Polasky, 2002 ). Sustainability in agriculture is described by the National Campaign for Sustainable Agriculture as "one that is simultaneously economically viable, environmentally sound, socially just, and humane" (Shreck, Feenstra, \& Getz, 2006, p. 440). Today's farms must strive to meet social, economic, and environmental goals to achieve sustainability. Farms that do not meet these goals will not last long (Rayburn, et al., 2006). 
Farmer incentives are a major issue confronting sustainable agriculture (Tilman et al., 2002 ). Today, the U.S. government continues to expand programs and funding available to farmers who produce agricultural products to assist in achieving sustainability. Nationally, a prominent example of a federal program is the Environmental Quality Incentives Program (EQIP). The Environmental Quality Incentives Program (EQIP), administered by the USDA Natural Resources Conservation Service (NRCS), is growing in budget and scope (Bailey \& Merrigan, 2010). EQIP provides incentive payments and technical assistance for farmers who implement conservation practices, or activities like conservation planning, with the goal to improve natural resources and deliver environmental benefits (NRCS, 2014). In West Virginia the Cooperative Extension Service, West Virginia Department of Agriculture, and the West Virginia Conservation Agency are examples of government entities which offer programs to assist farmers to reach their goals.

Universities and agencies across the nation have developed agricultural and production guidelines called Best Management Practices (BMPs). BMPs focus on management of inputs to provide for economic, environmental and agronomic sustainability in agriculture. One of the goals of BMPs is to reduce degradation of water resources by agricultural practices (Brown, Boone, Nokes, \& Ward, 2014).

Grazing beef cattle in pasture fields is a common agriculture practice which could potentially impact water sources negatively. For example, treading may lead to soil compaction which decreases water infiltration and increases surface runoff (Krueger, et al., 2002). A possible solution to remedy this problem, according to BMPs, is to use rotational stocking to minimize the opportunity livestock have to form trails and to develop a riparian buffer to intercept organic material, fertilizer, pesticides, and other pollutants in surface runoff (Ball, Hoveland, \& Lacefield, 2007) (Watershed Resource Center, n.d.).

The way to achieve sustainability of grazing lands is through the management practices of vegetative covering of the land. It not only provides feed for livestock but 
also controls erosion, filters water, and recycles nutrients (Krueger, et al., 2002). Other important BMPs for grazing livestock include: planting vegetative covering of cleared land, removing animals from steep pastures when wet, avoid feeding hay on slopes or near streams, apply lime and fertilizers according to soil test recommendations, and extending the grazing season to lower expenses and utilize higher quality of forage (Ball, Hoveland, \& Lacefield, 2007; and Ball, Ballard, Kennedy, Lacefield, \& Undersander, 2007).

\section{Problem Statement}

Pasture forage is a vital commodity to sustainable livestock production and is the most predominant agriculture product in West Virginia (West Virginia Department of Agriculture, 2011). Subsequently, the West Virginia beef industry, located in all fiftyfive counties, sold an estimated 194,147 beef cows valued over 165 million dollars (United States Department of Agriculture, 2012). Presently, not enough information exists to accurately assess the grazing management practices among West Virginia beef producers. More information is needed to evaluate the level of adoption of BMPs for pastured-based livestock systems and develop appropriate educational programs.

\section{Purpose and Objectives}

The purpose of this study is to determine the current grazing management practices among West Virginia beef producers. The study can be compared to a "snapshot in time" to obtain an understanding of the current status of BMP usage among beef farmers. Understanding the beef producers' current grazing practices can lead to improved grazing information distributed to producers that can benefit all producers and land management. 


\section{Research Questions}

The objectives of study were reflected in the following research questions:

1. What is the distribution of beef operation classifications among West Virginia beef producers?

2. What are the characteristics of farmland used for grazing?

3. What are the current grazing management practices among West Virginia beef producers?

4. Are selected BMPs being implemented on the farm?

5. What do farmers perceive as barriers to rotational grazing?

\section{Limitations of Study}

Contact information is only available for those beef producers that have participated in the following: Southern Bull Test, Beef Quality Assurance program, The West Virginia Cattlemen's Association, South Branch and Weston Livestock Market Sales, and the State Beef Livestock Round-Up. 


\section{CHAPTER 2}

\section{Review of Literature}

According to the 2012 Census of Agriculture, West Virginia's farm land is predominantly pastureland. Permanent pastureland accounts for nearly thirty-two percent of total farm land. Forty-seven percent of the total farms in West Virginia incorporated beef cattle. West Virginia's beef industry, which operates in all fifty-five counties, sold 194,147 beef cows valued over 165 million dollars. The state's average size farm is around 165 acres, up from 157 acres in 2007 (United States Department of Agriculture, 2012).

\section{Current Grazing Practices}

An Iowa State University Extension Service (2007) grazing study focused on beef producers' pasture and grazing management practices and overall farm operation. Areas of focus included: number of paddocks, soiling testing, weed control, water system and source, waterway access, winter feeding, stocking rate/pasture, forage composition, fertilizing, and district location. The results indicated that while some BMPs are being utilized others are not. For example, the study found that $68 \%$ of farmers rotationally grazed between four or more fields. It also found that only $33 \%$ soil test every five years or less and $25 \%$ limit access to waterways.

Paine and Gildersleeve (2011) broke down Wisconsin's beef producers into two categories: management intensive grazing (MiG) and non-management intensive grazing. The two categories were then compared on grazing practices and characteristics. Noteworthy outcomes of the study were MiG farms had lower production costs per cow than non-MiG farms and both groups had low participation in government conversation programs; $12 \% \mathrm{MiG}$ and $11 \%$ non-MiG. 


\section{Barriers to Rotational Grazing}

Farmers' perception of rotational grazing is potentially a barrier from implementing the practice on their farm. The barriers as perceived by farmers' include but not limited to: capital start-up investment, availability of land, decrease of farm profits, lack of information and on-farm technical assistance, workload in starting and maintaining the system, winter feeding, and skepticism from family and other farmers (Franzluebbers et al., 2012). A 2011 study managed by the University of Maryland Center for Environmental Science revealed that farmers in central Maryland perceived tradition, peer-pressure, and lack of confidence as barriers. Beginning dairy farmers in Wisconsin felt barriers were experience, capital, and land whereas experienced farmers believed lifestyle, land, and measures of success were barriers (Merrill, 2006). Also, farmers in the northeast United States found perceived land, finances, labor, and risk as barriers (Winrock International, n.d.).

Despite the barriers, the number of beef producers implementing management intensive rotational grazing is increasing. During the 1990s in Wisconsin, the MiG adoption rate was at $31 \%$. As of 2007 the adoption rate rose to $42 \%$, an increase of $11 \%$. Ninety percent of beef producers who implemented MiG were either satisfied or very satisfied with their system (Paine \& Glidersleeve, 2011).

\section{Summary}

Current research indicates beef producers are implementing Best Management Practices (BPMs) into their farm system(s). While some barriers offer challenges to implementing these practices, they can be overcome. Research is available to understanding the barriers and level of adoption of BMPs adoption at the national level, but there is little information available on these variables for West Virginia beef producers. In order to achieve sustainability in West Virginia beef production, it is essential to understand which grazing practices are currently being utilized and barriers to expanding sustainable farming practices. 


\section{CHAPTER 3}

\section{Research Methods and Procedures}

\section{Purpose and Objectives}

The purpose of this study is to determine the current grazing management practices among West Virginia beef producers. The study can be compared to a "snapshot in time" to obtain an understanding of the current status of BMP usage among beef farmers. Information from this study can be used to help promote best agriculture management practices and to develop appropriate educational programs.

\section{Research Questions}

The objectives of study were reflected in the following research questions:

1. What is the distribution of beef operation classifications among West Virginia beef producers?

2. What are the characteristics of farmland used for grazing??

3. What are the current grazing management practices among West Virginia beef producers?

4. Are selected BMPs being implemented on the farm?

5. What do farmers perceive as barriers to rotational grazing?

\section{Research Design}

This study used the descriptive research methodology to evaluate the research questions. Descriptive research's main objective is to explore and describe what is currently happening in relationship to what is being studied. Surveys are commonly used to reach the desired population regardless of location. Surveys also allow researchers to measure attitudes and opinions from a sample of the target population (Ary, Jacobs, \& Sorenson, 2010). 


\section{Population}

The target population for this study was all beef producers in West Virginia. Since an official list for all beef producers is unavailable, the accessible population was selected from a complied list of participants in the Southern Bull Test, Beef Quality Assurance Program, The West Virginia Cattlemen's Association, South Branch and Weston livestock markets, and the State Beef Livestock Round-Up ( $\mathrm{N}=4600)$. Using Krejcie and Morgan (1960) guidelines the total sample size of the beef producers needed for analysis representative sample was determined to be 355 .

\section{Instrumentation}

A mailed questionnaire was used for gathering data. Surveys are great tools to measure the intangibles, like attitudes and beliefs, while simultaneously measuring the tangibles. A survey allows for public opinions without coming into contact with the participants. The survey for this research was developed using information from Iowa State University Extension Service grazing survey (2007) and modified for West Virginia.

The survey instrument was broken down into four parts. The first part consisted of 17 checklist and open-ended questions used to determine general farm characteristics and management. The second part consisted of 50 numeric rating scale type questions. These questions were design to evaluate the importance of livestock grazing practices in relation to their farm. The participants indicated the practice's importance and frequency on a scale from one to ten, with one being no importance/no occurrence and ten being extremely important/frequently occurring. The third section consisted of 13 Likert-type questions. These questions were design to evaluate the attitudes and perceptions about barriers to rotational grazing systems. There were five possible options to choose from in the answer set: strongly agree, agree, disagree, strongly disagree, and not applicable. Finally, the fourth part consisted of four questions used to gather demographic information. 


\section{Validity of the Instrument}

The instrument was presented to a committee of experts in the Agricultural and Extension Education department and Forage Extension Specialist at West Virginia University. Each individual on the committee had extensive teaching or Extension experience. The committee determined that the instrument had content and face validity.

\section{Reliability of the Instrument}

The reliability of the instrument was determined using the final data set. The Spearman Brown split-half statistic was used to establish reliability. Reliability was found to be exemplary with a coefficient of 0.69 (Robinson, Shaver, \& Wrightsman, 1991). The questionnaire was determined as a reliable measure.

\section{Data Collection}

Dillman's Tailored Design Method (2007) was adopted for this study. A packet was mailed to 355 beef producers on March 7, 2014 with the following content: a cover letter explaining the purpose of the study, the survey, and a self-addressed envelope. Participants were given a deadline of March 28, 2014 to return the questionnaire. A second mailing packet was sent to all non-respondents on April 2, 2014. This packet included: an additional follow-up cover letter, the instrument, and prepaid envelopes. The second mailing deadline was April 18, 2014.

\section{Data Analysis}

To avoid non-response error, a comparison between early and late respondents to find differences was conducted using the Pearson Chi-Square. The variables used for the Chi-Square test were early/late respondents and full-time/part-time farmers. The ChiSquare showed no significant differences between variables; therefore generalizations could be made for the total population. Beef producers were randomly selected using 
SPSS statistical software to avoid sampling error. To avoid frame error the beef producers list was created from six participant lists: the Southern Bull Test, Beef Quality Assurance Program, The West Virginia Cattlemen's Association mailing list, two South Branch and Weston livestock markets, and the State Beef Livestock Round-Up.

Selection error was avoided by deleting any duplicate names from the population list.

The data was entered in an Excel spreadsheet. The data was then transferred to SPSS for analysis. The significant level was set $a$ priori at $\leq .05$ for all statistical tests. Frequencies and percentages were used to analyze the data. 


\section{CHAPTER 4}

\section{Findings}

\section{Purpose and Objectives}

The purpose of this study is to determine the current grazing management practices among West Virginia beef producers. The study can be compared to a "snapshot in time" to obtain an understanding of the current status of BMP usage among beef farmers. Information from this study can be used to help promote best agriculture management practices and to develop appropriate educational programs.

\section{Research Questions}

The objectives of study were reflected in the following research questions:

1. What is the distribution of beef operation classifications among West Virginia beef producers?

2. What are the characteristics of farmland used for grazing??

3. What are the current grazing management practices among West Virginia beef producers?

4. Are selected BMPs being implemented on the farm?

5. What do farmers perceive as barriers to rotational grazing?

\section{Findings}

The targeted population for this study comprised of beef producers from West Virginia. The population sample of 355 was randomly selected. Eighteen were returned as undeliverable, one was deceased, one was no longer farming, and one was a duplicate mailing address making the sample population 334. Out of 334 questionnaires 103 (31\%) were returned. 
Responses of West Virginia beef producers were summarized and results of the

data analysis are presented in the following areas: farm characteristics and management, stocking rates, pasture plant composition, extending the grazing season, water, weed management, barriers to rotational grazing, and demographics. Data obtained from this study were analyzed by frequencies, percentages and means.

\section{Conservation district represented by respondents.}

All respondents were asked to identify the county in which their farm is located. The location was then categorized into West Virginia's soil districts and reported as such. None of the respondents' farms were located in the Capital and Eastern Panhandle soil district, five were located in the Elk district (5.1\%), nine farms were in the Greenbrier district $(9.1 \%)$, one farm was from the Guyan district (1.0\%), 11 were located in the Little Kanawha district (11.1\%), six were located in the Monongahela district (6.1\%), four were in the Northern Panhandle district (4.0\%). Twenty-five reported their farms were located in the Potomac Valley district (25.3), three were in the Southern district (3.0\%), 10 were located in the Tygarts Valley district (10.1\%), three were in the Upper Ohio district (3.0\%), seven were located in the Western district (7.1\%), and 15 were in the West Fork district (15.2\%) (see Table 1). 
Table 1

Conservation District Represented by Respondents

\begin{tabular}{|c|c|c|}
\hline & $\mathrm{n}$ & $\%$ \\
\hline Capital & 0 & .0 \\
\hline Eastern Panhandle & 0 & .0 \\
\hline Elk & 5 & 5.1 \\
\hline Greenbrier Valley & 9 & 9.1 \\
\hline Guyan & 1 & 1.1 \\
\hline Little Kanawha & 11 & 11.1 \\
\hline Monongahela & 6 & 6.1 \\
\hline Northern Panhandle & 4 & 4.0 \\
\hline Potomac Valley & 25 & 25.3 \\
\hline Southern & 3 & 3.0 \\
\hline Tygarts Valley & 10 & 10.1 \\
\hline Upper Ohio & 3 & 3.0 \\
\hline Western & 7 & 7.1 \\
\hline West Fork & 15 & 15.2 \\
\hline
\end{tabular}

\section{Grazing season length.}

When West Virginia beef producers were asked the length of the grazing season on their farm, one respondent's grazing length was less than five months (1.0\%). Fortytwo responded the grazing length as five to six months $(41.2 \%), 50$ responded their season was seven to eight months $(49.0 \%)$, and nine respondents indicated the grazing season was greater than eight months $(8.8 \%)$ (see Table 2$)$. 
Table 2

Grazing Season Length

\begin{tabular}{lcc}
\hline & $\mathrm{n}$ & $\%$ \\
\hline$<5$ months & 1 & 1.0 \\
$5-6$ months & 42 & 41.2 \\
$7-8$ months & 50 & 49.0 \\
$>8$ months & 9 & 8.8 \\
\hline
\end{tabular}

\section{Classification of grazing system.}

Respondents were asked to describe their farm's grazing system using five categories. Twenty-six indicated their system as a continuous (one pasture) system (26.5\%), 49 were using two to four pastures (50.0\%), 14 were using five to seven pastures $(14.3 \%)$, eight indicated using eight or more pastures $(8.2 \%)$, and one farmer implemented strip grazing as the preferred grazing system (1.0\%) (see Table 3 ).

Table 3

Classification of Grazing System on Farm

\begin{tabular}{lcc}
\hline & $n$ & $\%$ \\
\hline Continuous & 26 & 26.5 \\
2-4 Fields & 49 & 50.0 \\
5-7 Fields & 14 & 14.3 \\
8+ Fields & 8 & 8.2 \\
Strip Grazing & 1 & 1.0 \\
\hline
\end{tabular}




\section{Beef operation classification.}

Respondents were asked to classify their beef operation. Seventy-five producers classified their beef operation as cow-calf (72.8\%), seven indicated their system as stocker, backgrounder, grower (6.8\%), 20 classified their system as mixed (cow-calf and stocker) (19.4\%), and one selected other (1.0\%) (see Table 4).

Table 4

Beef operation classification

\begin{tabular}{lcc}
\hline & $\mathrm{n}$ & $\%$ \\
\hline Cow-calf & 75 & 72.8 \\
Stocker, backgrounder, grower & 7 & 6.8 \\
Feedlot & 0 & 0.0 \\
Mixed - Cow-calf and Stocker & 20 & 19.4 \\
Other & 1 & 1.0 \\
\hline
\end{tabular}

\section{Soil test frequency.}

Respondents were asked how frequently they test the pasture's soil using five categories. Six responding they test every year (5.8\%), 12 soil test once every two years (11.7\%), 25 soil test once every three years (24.3\%), 36 soil test once every four years or more (35.0\%), and 24 indicated that they do not test the pasture's soil (23.3\%) (see Table $5)$. 
Table 5

Frequency of Soil Testing

\begin{tabular}{lcc}
\hline & $\mathrm{n}$ & $\%$ \\
\hline Every year & 6 & 5.8 \\
Once every two years & 12 & 11.7 \\
Once every three years & 25 & 24.3 \\
Once every four years or more & 36 & 35.0 \\
Do Not test soil & 24 & 23.3 \\
\hline
\end{tabular}

\section{Fertilizer application frequency.}

Respondents were asked how frequently they applied fertilizer to their pasture using six categories. Eighteen respondents added fertilizer every year (17.5\%), 14 added fertilizer every two years (13.6\%), eight added every three year (7.8\%), while 20 added fertilizer as prescribed by the soil test results (19.4\%). Twenty indicated they do not use fertilizer (19.4\%) (see Table 6).

Table 6

Frequency of Applying Fertilizer

\begin{tabular}{lcc}
\hline & $\mathrm{n}$ & $\%$ \\
\hline Every year & 18 & 17.5 \\
Once every two years & 14 & 13.6 \\
Once every three years & 8 & 7.8 \\
Once every four or more years & 23 & 22.3 \\
As recommended by soil test & 20 & 19.4 \\
Do not use fertilizer & 20 & 19.4 \\
\hline
\end{tabular}




\section{Frequency of lime treatment.}

Respondent were asked how frequently they lime their pasture. One respondent indicated they lime every year (1.0\%), six lime every two years (5.9\%), 16 lime every three years $(15.7 \%), 30$ responded every four years or more $(29.4 \%)$, while 32 lime as recommended by the soil test results $(31.3 \%)$. Seventeen farmers reported they do not add lime (16.7\%) (see Table 7).

Table 7

Frequency of Lime Treatment

\begin{tabular}{lcc}
\hline & $\mathrm{n}$ & $\%$ \\
\hline Every year & 1 & 1.0 \\
Once every two years & 6 & 5.9 \\
Once every three years & 16 & 15.7 \\
Once every four or more years & 30 & 29.4 \\
As recommended by soil test & 32 & 31.4 \\
Do not lime & 17 & 16.7 \\
\hline
\end{tabular}

\section{Acreage used for grazing.}

Beef producers were asked how many acres were used for grazing, how many acres of hayland were present and how many acres of hayland were used for grazing after first cut, and how many acres of corn were present and how many acres of corn stover were used for grazing. The mean farmland grazing acreage was 138.0 acres (see Table 8). Grazing land acreage distribution had a standard deviation of 142.9 , with a maximum of 600 , and a minimum of eight acres (see Table 8). The mean acreage of hayland was 59.5 (see Table 8). Hayland acreage distribution had a standard deviation of 57.0, maximum of 235, and minimum of zero. The mean acreage of hayland used for grazing after first cut was 23.9 (see Table 8). The distribution of the acreage of hayland used for 
grazing after first cut had a standard deviation of 39.0, maximum of 210, and minimum of zero. The mean acreage of corn was 7.3 acres (see Table8). Acreage of corn distribution had a standard deviation of 30.0, with maximum of 275 acres, and minimum of zero. The mean acreage of corn stover used for grazing was 3.4 acres (see Table 8). The distribution of corn stover acreage used for grazing cut had a standard deviation of 20.8 , with a maximum of 195 , and minimum of zero acres.

Table 8

Acreage used for Grazing

\begin{tabular}{lrrrc}
\hline & $\mathrm{m}$ & $\mathrm{sd}$ & $\mathrm{min}$ & $\max$ \\
\hline Acres used for grazing & 138.0 & 142.9 & 8 & 600 \\
Acres of hayland & 59.5 & 57.0 & 0 & 235 \\
Acres of hayland used for grazing after 1st & 23.9 & 39.0 & 0 & 210 \\
cut & & & & \\
Acres of corn & 7.3 & 30.0 & 0 & 275 \\
Acres of corn stover used for grazing & 3.4 & 20.8 & 0 & 195 \\
\hline
\end{tabular}

\section{Stocking rate.}

Respondents were asked about stocking rates on their farm. The mean for calves sold in fall was 24.0 head (see Table 9). Calves sold in fall distribution had a standard deviation of 22.7, with a maximum of 120 head, and a minimum of zero. The mean for calves over-winter was 25.6 (see Table 9). Calves held over winter distribution had a standard deviation of 47.8 , with a maximum of 250 , and a minimum of zero. The mean for over-wintered calves sold in spring was 14.3 head (see Table 9). The distribution of over-wintered calves sold in spring was 40.3, with a maximum of 200 head, and a minimum of zero. Stocker cattle bought in the fall reported to be a mean of 5.9 head (see Table 9). The distribution for stocker cattle bought in the fall had a standard deviation of 29.2 , with a maximum 250 head, and a minimum of zero. Stocker cattle bought in the 
spring had a mean of 2.6 head (see Table 9). The stocker cattle bought in spring had a standard deviation of 9.9 head, with a maximum of 70 head, and a minimum of zero.

Table 9

Stocking Rate

\begin{tabular}{lcccc}
\hline & $\mathrm{m}$ & $\mathrm{sd}$ & $\mathrm{min}$ & $\max$ \\
\hline Calves sold in fall & 24.0 & 22.7 & 0 & 120 \\
Calves over-winter & 25.6 & 47.8 & 0 & 250 \\
Winter Calves sold in spring & 14.3 & 40.3 & 0 & 200 \\
Stocker cattle bought in fall & 5.8 & 29.2 & 0 & 250 \\
Stocker cattle bought in spring & 2.6 & 9.9 & 0 & 70 \\
\hline
\end{tabular}

\section{Importance of grass species in field composition.}

Respondents were asked to rate the importance of six grass species in their farm's field composition. Respondents rated the importance from zero - no importance through 10 - extremely important. The averages were categorized into the following descriptors: 0 - 0.5 no importance, 0.6 - 2.5 low importance, 2.6 - 4.5 minimal importance, 4.5 - 5.5 mild importance, 5.6 - 7.5 moderate importance, 7.6 - 9.5 high importance, and $9.6-10$ extreme importance.

The mean for bermudagrass was 0.7 with a standard deviation of 1.7 , indicating a low importance (see Table 10). Kentucky bluegrass had a mean of 4.4 with a standard deviation of 3.3 indicting minimal importance (see Table 10). The mean for orchardgrass was 7.5 with a standard deviation of 2.4 indicating a moderate importance (see Table 10). Perennial ryegrass had a mean of 2.3 with a standard deviation of 2.9 indicates respondents saw ryegrass as low importance (see Table 10). The mean of tall fescue was 4.8 and had a standard deviation of 3.5 indicating a mild importance (see Table 10). 
Lastly, timothy had a mean of 4.8 with a standard deviation of 3.3 had a mild response (see Table 10).

Table 10

Importance of Grass Species in Field Composition

\begin{tabular}{lcc}
\hline & $\mathrm{m}$ & $\mathrm{sd}$ \\
\hline Bermudagrass & 0.7 & 1.7 \\
Kentucky Bluegrass & 4.4 & 3.3 \\
Orchardgrass & 7.5 & 2.4 \\
Perennial ryegrass & 2.3 & 2.9 \\
Tall Fescue & 4.8 & 3.5 \\
Timothy & 4.8 & 3.3 \\
\hline
\end{tabular}

Importance of legume species in field composition.

Respondents were asked to rate the importance of four legume species in their farm's field composition. Respondents rated the importance from zero - no importance through 10 - extremely important. The averages were categorized into the following descriptors: 0 - 0.5 no importance, 0.6 - 2.5 low importance, 2.6 - 4.5 minimal importance, 4.5 - 5.5 mild importance, 5.6 - 7.5 moderate importance, 7.6 - 9.5 high importance, and 9.6 - 10 extreme importance.

Alfalfa was rated as low importance with a mean of 1.3 and a standard deviation of 2.5 (see Table 11). Birdsfoot trefoil's mean was 1.1 with a standard deviation of 1.9, indicting low importance (see Table 11). Red clover and white clover were rated as being moderate important by the respondents. The mean for red clover was 6.1 with a standard deviation of 3.0 and white clover had a mean of 7.0 with a standard deviation of 2.7 (see Table 11). 
Table 11

Importance of Legume Species in Field Composition

\begin{tabular}{lcc}
\hline & $\mathrm{m}$ & $\mathrm{sd}$ \\
\hline Alfalfa & 1.3 & 2.5 \\
Birdsfoot trefoil & 1.1 & 1.9 \\
Red clover & 6.1 & 3.0 \\
White clover & 7.0 & 2.7 \\
\hline
\end{tabular}

\section{Extending grazing during the summer slump.}

Respondents were asked to indicate the frequency of five methods to extend the grazing season during the summer slump of forage production used on their farm.

Respondents rated the frequency from zero - not used through 10 - used extensively. The averages were categorized into the following descriptors: 0 - 0.5 not used, 0.6 - 2.5 low usage, 2.6 - 4.5 minimal usage, 4.5 - 5.5 mild usage, 5.6 - 7.5 moderately used, 7.6 9.5 highly used, and $9.6-10$ used extensively.

The mean for grazing on warm-season perennial grasses was 1.5 and had a standard deviation of 2.6, indicating low usage (see Table 12). Grazing on warm-season annual grasses had a mean of 0.7 with a standard deviation of 1.9 and selling to reduce herd had a mean of 1.5 with a standard deviation of 2.7 (see Table 12). The mean for grazing the aftermath on hayfields was 5.0 with a standard deviation of 3.9 , indicating a mild usage (see Table 12). Lastly, the mean for no summer slump and brush-hog excess was 4.7 and had a standard deviation of 3.6, also indicating mild use (see Table12). 
Table 12

Methods to Extend Grazing during the Summer Slump

\begin{tabular}{lll}
\hline & $\mathrm{m}$ & $\mathrm{sd}$ \\
\hline Graze on warm-season perennial grass & 1.5 & 2.6 \\
Graze on warm-season annual grass & 0.7 & 1.9 \\
Graze aftermath of hayfield & 5.0 & 3.9 \\
Sell to reduce herd & 1.5 & 2.7 \\
No summer slump brush-hog excess & 4.7 & 3.6 \\
\hline
\end{tabular}

\section{Extending grazing into winter and early spring.}

Respondents were asked to indicate the frequency of six methods to extend the grazing season during winter and early spring used on their farm. Respondents rated the frequency from zero - not used through 10 - used extensively. Respondents rated the frequency from zero - not used through 10 - used extensively. The averages were categorized into the following descriptors: 0 - 0.5 not used, 0.6 - 2.5 low usage, 2.6 - 4.5 minimal usage, 4.5 - 5.5 mild usage, 5.6 - 7.5 moderately used, 7.6 - 9.5 highly used, and 9.6 - 10 used extensively.

Stockpiling forage for had a mild usage for winter and minimal usage for early spring. The mean for stockpiling forage for winter was 5.1 and had a standard deviation of 4.3 (see Table 13). Also the mean for stockpiling forage for early spring was 3.6 and had a standard deviation of 4.3 (see Table 13). Wind rowing forage for winter grazing had a mean of 0.1 with a standard deviation of 0.6 (see Table 13). Wind rowing forage for winter or spring consumption was not used by farmers. Wind rowing forage for early spring had a mean of 0.1 with a standard deviation of 0.8 (see Table 13). The mean for planting winter annual grass for winter grazing was 0.7 with a standard deviation of 2.0 (see Table 13). Also, planting brassicas and annual legumes for either winter or early spring were not used by farmers. Planting brassicas for winter grazing had a mean of 0.3 
with a standard deviation of 1.2 (see Table 13). Planting brassicas for early spring had a mean of 0.1 with a standard deviation of 0.6 (see Table 13). The mean for planting winter annual legumes for winter grazing was 0.2 and had a standard deviation of 0.8 (see Table13). The mean for planting winter annual legumes for early spring was 0.2 and had a standard deviation of 0.9 (see Table13). Planting winter annual grass for winter and early spring had low usage and no usage among farmers, respectively. The mean for planting winter annual grass for early spring was 0.4 with a standard deviation of 1.7 (see Table 13). Selling to reduce herd size for winter or early spring had a low usage among farmers. The mean of selling to reduce herd size for winter 1.7 and a standard deviation of 2.9 (see Table13). Selling to reduce herd size for early spring had a mean of 1.0 with a standard deviation of 2.3 (see Table13).

Table 13

Methods for Extending Grazing into Winter and Early Spring

\begin{tabular}{lllll}
\hline & \multicolumn{2}{c}{ Winter } & \multicolumn{2}{c}{ Early Spring } \\
& $\mathrm{m}$ & $\mathrm{sd}$ & $\mathrm{m}$ & $\mathrm{sd}$ \\
\hline Stockpile forage & 5.1 & 4.3 & 3.6 & 4.3 \\
Windrow & 0.1 & 0.6 & 0.1 & 0.8 \\
Plant winter annual grass & 0.7 & 2.0 & 0.4 & 1.7 \\
Plant brassicas & 0.3 & 1.2 & 0.1 & 0.6 \\
Plant winter annual legume & 0.2 & 0.8 & 0.2 & 0.9 \\
Sell to reduce herd & 1.7 & 2.9 & 1.0 & 2.3 \\
\hline
\end{tabular}

\section{Pasture water distribution systems.}

Respondents were asked to rate the importance of 11 pasture watering techniques on their farm. Respondents rated the importance from zero - no importance through 10 extremely important. The averages were categorized into the following descriptors: 0 0.5 no importance, 0.6 - 2.5 low importance, 2.6 - 4.5 minimal importance, 4.5 - 5.5 mild 
importance, 5.6 - 7.5 moderate importance, 7.6 - 9.5 high importance, and 9.6 - 10 extreme importance.

The mean for livestock having direct access to pond water was 5.3 and had a standard deviation of 4.1, indicating a mild importance; whereas pumping pond water into a storage vessel had a mean of 3.3 with a standard deviation of 4.4, indicating a low importance (see Table 14). Livestock having direct access to spring water had a mild importance with a mean of 5.3 and had a standard deviation of 4.1 (see Table 14). Pumping spring water into a storage vessel had a mean of 3.6 with a standard deviation of 4.4, indicating a low importance among farmers (see Table 14). Livestock having direct access to streams and creeks had a mild importance with a mean of 5.6 and had a standard deviation of 3.9 (see Table 14). Pumping stream/creek water into a storage vessel had low importance with a mean of 0.5 and a standard deviation of 1.9 (see Table 14). Supplying drilled well water directly to paddock had a low importance among farmers. The mean for supplying drilled well water directly to paddock was 3.0 with a standard deviation of 4.0 (see Table 14). Supplying city water to paddocks had a low importance among respondents. The mean for supplying city water directly to paddock had a mean of 2.4 with a standard deviation of 3.8 (see Table 14). A centralized water station had a low importance among farmers. The mean for a centralized water station was 1.8 with a standard deviation of 3.4 (see Table14). A movable water source to paddocks also had low importance. The mean for movable water source was 0.6 with a standard deviation of 1.8 (see Table 14). Hauling water to permanent holding vessel in paddock had no importance among farmers. The mean was 0.2 with a standard deviation of 0.7 (see Table 14). 
Table 14

Pasture Water Distribution Systems

\begin{tabular}{lll}
\hline & $\mathrm{m}$ & $\mathrm{sd}$ \\
\hline Pond water, direct access & 5.3 & 4.1 \\
Pond water, pump into storage vessel & 3.3 & 4.4 \\
Natural spring, direct access & 5.3 & 4.2 \\
Natural spring, pump into storage vessel & 3.6 & 4.4 \\
Stream, creek, direct access & 5.6 & 3.9 \\
Stream, creek, pumped into storage vessel & 0.5 & 1.9 \\
Drilled-well water directly to paddock & 3.0 & 4.0 \\
City water directly to paddock & 2.4 & 3.8 \\
Centralized water station & 1.8 & 3.4 \\
Movable water source to paddocks & 0.6 & 1.8 \\
Hauled to permanent holding vessel in & 0.2 & 0.7 \\
paddocks & & \\
\hline
\end{tabular}

\section{Natural waterway buffer zones.}

Respondents were asked to indicate the occurrence of buffer zones for waterways found on their farm. Respondents rated the occurrence from zero - no occurrence through 10 -frequently occurring. The averages were categorized into the following descriptors: 0 - 0.5 no occurrence, 0.6 - 2.5 low occurrence, 2.6 - 4.5 minimal occurrence, 4.5 - 5.5 mild occurrence, 5.6 - 7.5 moderate occurrence, 7.6 - 9.5 high occurrence, and $9.6-10$ extreme occurrence.

Buffer zone comprised of grass mildly occurred throughout the pasture(s) as indicating by the farmers. The mean for the buffer zone comprised of grass was 5.1 and had a standard deviation of 3.8 (see Table 15). Buffer zone comprised of shrubs had a low occurrence throughout the pasture(s). The mean for buffer zone comprised of shrubs 
was 1.9 and with a standard deviation of 2.8 (see Table 15). Farmers indicated that buffer zones comprised of trees had a minimal occurrence in the pasture(s). The mean for buffer zone comprised of trees was 3.4 and had a standard deviation of 3.2 (see Table 15). Farms with no buffer zone but water ways blocked by fencing had a low occurrence with a mean of 2.4 and a standard deviation of 3.5 (see Table 15). Farms with no buffer zone and water ways were accessible to livestock occurred minimally with a mean of .4.0 and a standard deviation of 3.9 (see Table 15). Lastly, no natural water way on farm had occurred low with a mean of 2.2 and a standard deviation of 3.4 (see Table 15).

Table 15

Natural Waterway Buffer Zones

\begin{tabular}{lcc}
\hline & $\mathrm{m}$ & $\mathrm{sd}$ \\
\hline Buffer zone comprised of grass & 5.1 & 3.8 \\
Buffer zone comprised of shrubs & 1.9 & 2.8 \\
Buffer zone comprised of trees & 3.4 & 3.2 \\
No buffer zone, water ways blocked by & 2.4 & 3.5 \\
fencing & & \\
No buffer zone, water ways accessible to & 4.0 & 3.9 \\
livestock & & \\
No natural water ways on farm & 2.2 & 3.4 \\
\hline
\end{tabular}

Weed control methods.

Respondents were asked to indicate the frequency of six methods used to control weeds on their farm. Respondents rated the frequency from zero - not used through $10-$ used extensively. The averages were categorized into the following descriptors: 0 - 0.5 not used, 0.6 - 2.5 low usage, 2.6 - 4.5 minimal usage, 4.5 - 5.5 mild usage, 5.6 - 7.5 moderately used, 7.6 - 9.5 highly used, and 9.6 - 10 used extensively. 
Farmers indicated a mild usage for herbicide control and cultural control of weeds. Herbicide control had a mean of 4.4 with a standard deviation of 3.5 (see Table 16). The mean for cultural control was 5.0 and had a standard deviation 3.7 (see Table 16). Mechanical-physical control for weeds was moderately used among respondents. The mean for mechanical-physical control was 7.4 with a standard deviation 2.8 (see Table 16). The biological controls for weeds from co-grazing and grazing at different times had a low usage among farmers. Co-grazing biological control had a mean of 1.7 with a standard deviation of 3.0 (see Table 16). The mean for grazing at different times biological control was 1.7 and had a standard deviation of 2.9 (see Table 16). Lastly, producers who do not control weeds had a mean of 3.1 with a standard deviation of 3.5 , indicating a minimal usage practice (see Table 16).

Table 16

Weed Control Methods

\begin{tabular}{lcc}
\hline & $\mathrm{m}$ & $\mathrm{sd}$ \\
\hline Herbicide control & 4.4 & 3.5 \\
Mechanical-physical control & 7.4 & 2.8 \\
Cultural control & 5.0 & 3.7 \\
Biological control, co-grazing & 1.7 & 3.0 \\
Biological control, different times & 1.7 & 2.9 \\
Do not control weeds & 3.1 & 3.5 \\
\hline
\end{tabular}

\section{Barriers to rotational grazing as perceived from producers.}

Respondents in the study were instructed to rate their perception of barriers to rotational grazing on a five point Likert scale by circling the letters in the box that best corresponds to their response. The Likert scale choices consisted of: strongly agree, agree, disagree, strongly disagree, and not applicable. A total of 13 barriers were rated by the producers. 
Forty-eight (50.5\%) producers agreed that not enough land is a barrier to rotational grazing while $36(37.9 \%)$ producers disagreed. Eleven (11.6\%) producers responded not applicable (see Table 17). Sixty-nine (71.9\%) of respondents agreed that cost of fencing was a barrier to grazing. Twenty-two $(23.0 \%)$ respondents disagreed that cost of fencing was a barrier and five (5.2\%) selected not applicable (see Table 17). Fifty-one $(54.8 \%)$ producers agreed that availability of forage is a barrier to rotational grazing whereas Thirty-five $(37.6 \%)$ producers disagreed. Seven $(7.5 \%)$ producers selected not applicable (see Table 17).

Fifty-nine $(62.5 \%)$ respondents agreed that increase in labor was a barrier to rotational grazing while $28(29.5 \%)$ respondents disagree. Eight $(8.4 \%)$ responded not applicable. (see Table 17). Sixty-three $(66.3 \%)$ producers agreed that increase in time was a barrier to rotational grazing. Twenty-seven (38.4\%) producers disagreed that increase in time was a barrier and five (5.3\%) producers selected not applicable (see Table 17).

Forty-six (49.5\%) respondents agreed that predicting or determining forage availability was a barrier to rotational grazing while thirty-eight (40.9\%) respondents disagreed. Nine (9.7\%) respondents chose not applicable (see Table 17). Forty-four $(47.9 \%)$ respondents agreed that determining stocking rate was a barrier to rotational grazing. Thirty-nine (42.4\%) respondents disagreed and nine $(9.8 \%)$ respondents chose not applicable (see Table 17).

Seventy $(72.1 \%)$ producers agreed that providing water to livestock was a barrier to rotational grazing while $19(19.6 \%)$ producers disagreed. Eight $(8.3 \%)$ producers responded not applicable (see Table 17). Forty-eight (51.6\%) producers disagreed that animal performance was a barrier to rotational grazing while $35(37.7 \%)$ producers agreed. Ten (10.8\%) producers responded not applicable (see Table 17). 
Forty-six (48.4\%) respondents agreed that knowledge on grazing tolerant grass and legume species was a barrier to rotational grazing. Thirty-six (37.9\%) producers disagreed that knowledge on grazing tolerant grass and legume species was a barrier to rotational grazing and $13(13.7 \%)$ selected not applicable (see Table 17). Forty-eight $(51.1 \%)$ respondents disagreed that lack of information on pasture management was a barrier to rotational grazing while thirty-two (34.1\%) producers agreed. Fourteen (14.9\%) respondents selected not applicable (see Table 17).

Fifty-seven (60.6) producers disagreed that skepticism from other farmers was a barrier to rotational grazing while 19 (20.2\%) producers disagreed. Eighteen (19.1\%) producers responded not applicable (see Table 17). Fifty-four (57.4\%) producers disagreed that skepticism from family members was a barrier to rotational grazing while $18(\%)$ producers agreed. Twenty-two (23.4\%) producers responded not applicable (see Table 17). 
Table 17

Barriers to Rotational Grazing as Perceived from Producers

\begin{tabular}{|c|c|c|c|c|c|c|c|c|c|c|}
\hline & \multicolumn{2}{|c|}{ Not applicable } & \multicolumn{2}{|c|}{ Strongly disagree } & \multicolumn{2}{|c|}{ Disagree } & \multicolumn{2}{|c|}{ Agree } & \multicolumn{2}{|c|}{ Strongly agree } \\
\hline & $\mathrm{n}$ & $\%$ & $\mathrm{n}$ & $\%$ & $\mathrm{n}$ & $\%$ & $\mathrm{n}$ & $\%$ & $\mathrm{n}$ & $\%$ \\
\hline Not enough land pastures & 11 & 11.6 & 20 & 21.1 & 16 & 16.8 & 34 & 35.8 & 14 & 14.7 \\
\hline Cost of fencing & 5 & 5.2 & 11 & 11.5 & 11 & 11.5 & 45 & 46.9 & 24 & 25.0 \\
\hline Increase in labor & 8 & 8.4 & 11 & 11.6 & 17 & 17.9 & 43 & 45.3 & 16 & 16.8 \\
\hline Increase in time & 5 & 5.3 & 10 & 10.5 & 17 & 17.9 & 47 & 49.5 & 16 & 16.8 \\
\hline Availability of forage & 7 & 7.5 & 16 & 17.2 & 19 & 20.4 & 43 & 46.2 & 8 & 8.6 \\
\hline $\begin{array}{l}\text { Predicting or determining } \\
\text { forage availability }\end{array}$ & 9 & 9.7 & 13 & 14.0 & 25 & 26.9 & 38 & 40.9 & 8 & 8.6 \\
\hline Determining stocking rate & 9 & 9.8 & 11 & 12.0 & 28 & 30.4 & 34 & 37.0 & 10 & 10.9 \\
\hline $\begin{array}{l}\text { Providing water to } \\
\text { livestock }\end{array}$ & 8 & 8.3 & 6 & 6.2 & 13 & 13.4 & 43 & 44.3 & 27 & 27.8 \\
\hline $\begin{array}{l}\text { Knowledge on grazing } \\
\text { tolerant grass and legume } \\
\text { species }\end{array}$ & 13 & 13.7 & 8 & 8.4 & 28 & 29.5 & 40 & 42.1 & 6 & 6.3 \\
\hline $\begin{array}{l}\text { Lack of information on } \\
\text { pasture management }\end{array}$ & 14 & 14.9 & 15 & 16.0 & 33 & 35.1 & 26 & 27.7 & 6 & 6.4 \\
\hline
\end{tabular}


Table 17 (continued)

Barriers to Rotational Grazing as Perceived from Producers

\begin{tabular}{|c|c|c|c|c|c|c|c|c|c|c|}
\hline & \multicolumn{2}{|c|}{ Not applicable } & \multicolumn{2}{|c|}{ Strongly disagree } & \multicolumn{2}{|c|}{ Disagree } & \multicolumn{2}{|c|}{ Agree } & \multicolumn{2}{|c|}{ Strongly agree } \\
\hline & $\mathrm{n}$ & $\%$ & $\mathrm{n}$ & $\%$ & $\mathrm{n}$ & $\%$ & $\mathrm{n}$ & $\%$ & $\mathrm{n}$ & $\%$ \\
\hline $\begin{array}{l}\text { Skepticism from other } \\
\text { farmers }\end{array}$ & 18 & 19.2 & 21 & 22.3 & 36 & 38.3 & 14 & 14.9 & 5 & 5.3 \\
\hline $\begin{array}{l}\text { Skepticism from family } \\
\text { members }\end{array}$ & 22 & 23.4 & 22 & 23.4 & 32 & 34.0 & 13 & 13.8 & 5 & 5.3 \\
\hline Animal performance & 10 & 10.8 & 19 & 20.4 & 29 & 31.2 & 25 & 26.9 & 10 & 10.8 \\
\hline
\end{tabular}




\section{Demographics.}

Respondents were asked to identify if they were full-time or part-time producers. Thirty-six respondents indicated full-time producers (36.0\%) and 64 were part-time producers $(64.0 \%)$ (see Table 18$)$.

Table 18

Full Time vs Part Time Farmers

\begin{tabular}{lcc}
\hline & $\mathrm{n}$ & $\%$ \\
\hline Full-time & 36 & 36.0 \\
Part-time & 64 & 64.0 \\
\hline
\end{tabular}

When asked to identify their employment status, most farmers were either retired (38.8\%) or holding a full-time job off farm (37.8\%). Nine held part-time jobs off farm (9.2\%) and 14 did not have off-farm employment (14.3\%) (see Table 19)

Table 19

Employment Status of Producers

\begin{tabular}{lrc}
\hline & $\mathrm{n}$ & $\%$ \\
\hline Hold full-time job off farm & 37 & 37.8 \\
Hold part-time job off farm & 9 & 9.2 \\
Retired & 38 & 38.8 \\
Do not have off farm employment & 14 & 14.3 \\
\hline
\end{tabular}

The respondents were asked to identify their age using six categories. Three individuals indicated their age to be 30 years or below (3.0\%), six respondents listed their age to be in the $31-40$ years range $(6.0 \%), 14$ respondents were in the $41-50$ years range 
(14.0\%), 22 respondents indicated they were in the 51-60 years range (22.0\%), 39 indicated to be in the 61-70 years range (39.0\%), and 16 indicated to be over 70 years of age (16.0\%) (see Table 20).

Table 20

Average Age of Producer

\begin{tabular}{lcc}
\hline & $\mathrm{n}$ & $\%$ \\
\hline 30 years and below & 3 & 3.0 \\
$31-40$ years & 6 & 6.0 \\
$41-50$ years & 14 & 14.0 \\
$51-60$ years & 22 & 22.0 \\
$61-70$ years & 39 & 39.0 \\
Over 70 years & 16 & 16.0 \\
\hline
\end{tabular}

Finally, producers were asked to indicate their highest level of education successfully completed using six categories. One individual indicated they did not graduate high school (1.0\%), 38 respondents identified their highest level of education as a high school graduate (38.4\%), 14 indicated their level of education as some college (14.1\%), Seven of the respondents listed their highest level of education as a two-year college degree(7.1\%), 23 producers had a four-year college degree (23.2\%), and lastly 16 of the producers indicated their highest level of education as a graduate degree $(16.2 \%)$ (see Table 21). 
Table 21

Producers’ Highest Level of Education Completed

\begin{tabular}{lcc}
\hline & $\mathrm{n}$ & $\%$ \\
\hline Did not graduate high school & 1 & 1.0 \\
High school diploma or equivalent & 38 & 38.4 \\
Some college & 14 & 14.1 \\
Two year college degree & 7 & 7.1 \\
Four year college degree & 23 & 23.2 \\
Graduate degree & 16 & 16.2 \\
\hline
\end{tabular}




\section{CHAPTER 5}

\section{Summary and Conclusion}

\section{Purpose and Objectives}

The purpose of this study is to determine the current grazing management practices among West Virginia beef producers. The study can be compared to a "snapshot in time" to obtain an understanding of the current status of BMP usage among beef farmers. Information from this study can be used to help promote best agriculture management practices and to develop appropriate educational programs.

\section{Research Questions}

The objectives of study were reflected in the following research questions:

1. What is the distribution of beef operation classifications among West Virginia beef producers?

2. What are the characteristics of farmland used for grazing??

3. What are the current grazing management practices among West Virginia beef producers?

4. Are selected BMPs being implemented on the farm?

5. What do farmers perceive as barriers to rotational grazing?

\section{Summary}

The purpose of this study is to determine the current grazing management practices among West Virginia beef producers. The study consisted of 355 randomly selected West Virginia beef producers. Eighteen were returned as undeliverable, one was deceased, one was no longer farming, and one was a duplicate mailing address making the sample population 334. Out of 334 questionnaires 103 were returned for a response rate of $31 \%$. 
Research Question 1. What is the distribution of beef operation classifications among West Virginia beef producers?

The majority of beef producers (72.8\%) in West Virginia classify their operation as cow-calf. A mixed operation of cow-calf and stocker (19.4\%) was the second most response. No one indicated feedlot as their operating system.

Research Question 2. What are the characteristics of farmland used for grazing?

On average, the West Virginia beef operation utilizes 138 acres for grazing per farm. The average beef operation farm had 59.7 acres of hayland in which 23.9 acres of hayland are used for grazing after first cut. Also the average operation grew 7.3 acres of corn with 3.4 acres of corn stover used for grazing.

Research Question 3. What are the current grazing management practices among West Virginia beef producers?

With regard to stocking rates, on average respondents reported holding more calves over winter ( 26 head), followed by selling calves in the fall ( 24 head). Respondents reported selling on average 15 head of over wintered calves in spring to adjust their stoking rates. On average only three head of stocker cattle are bought in spring, while on average only six head of stocker cattle are bought in fall

The typical grazing length for producers ranged from five to eight months $(90.2 \%)$. Nine producers were able to graze over eight months $(8.8 \%)$ on their farm while one grazed less than five months.

The top two pasture grazing systems among producers consisted of two-four fields $(50.0 \%)$ and one continuous pasture (26.5\%). Eight percent of the farmers grazed on eight fields or more and one indicated strip grazing as their system. 
About one fourth of the farmers apply fertilizer every four years or more $(22.3 \%)$ while $19.4 \%$ do not use fertilizer at all. A little more the $19 \%$ of farmers apply fertilizer as recommended by the soil test.

A third of the producers apply lime when recommended by the soil test $(31.3 \%)$. Secondly, an additional third (29\%) of the producers apply lime every four years or more while only one percent (.98\%) applied lime every year.

Producers report Orchardgrass as the most important grass in their pasture. Timothy, tall fescue and Kentucky bluegrass were second, third, and fourth respectively. Perennial ryegrass had little importance and bermudagrass was not considered important.

White clover and red clover were important legumes in beef producers' pastures. Birdsfoot trefoil and alfalfa were not considered important.

The most important method to distribute drinking water to herd was to allow livestock direct access to pond, spring, and stream/creek water. Centralized water stations, hauling water, movable water sources, and pumping water from streams/creeks had no importance.

The most preferred weed control method was mechanical-physical control. Cultural control and herbicide were the second and third most method utilized. Biological control of co-grazing and grazing at different times were not widely used.

Research Question 4. Are BMPs being implemented on the farm?

Over one-third of the farms are mostly testing the soil every four years or more (34.9\%), whereas $23.3 \%$ do not practice soil testing. Approximately $17 \%$ of farmers test their soil at least once every two years and $24.2 \%$ test once every three years.

Grazing on hayfield aftermath was the most preferred method to extend grazing throughout the summer slump. Secondly, producers had no summer slump and brush hog 
the excess. Grazing on warm-season annual and perennial grass and selling to reduce herd was not an important method to extend grazing throughout the summer slump of forage production.

Stockpiling forage to was the preferred method to extend the grazing season in winter and early spring. Planting vegetation, windrowing, and selling to reduce herd were hardly used.

Natural waterway buffer zones comprised of trees most frequently occurred throughout producers' pasture(s). No buffer zone and water ways accessible to livestock occurred second most throughout the pasture(s).

Research Question 5. What do farmers perceive as barriers to rotational grazing?

The top four barriers to rotational grazing is providing water to livestock, cost of fencing, increase in labor, and increase in time, respectively. The top four barriers farmers disagreed with were skepticism from other farmers, skepticism from family members, animal performance, and lack of information on pasture management, respectively.

\section{Conclusion}

The following conclusions were made based on the results of the study:

1. The vast majority of West Virginia's beef production is a cow - calf operation.

2. Half of the surveyed beef producers are rotating between 2-4 pastures for grazing.

3. Orchardgrass is considered the most important grass species in beef production by producers. 
4. White clover is the most predominant legume in the pastures of beef operation.

5. The most common method for the beef industry to water its livestock is allowing direct access to streams and creeks.

6. Mechanical-physical control (ex: hand-pulling, brush-hog) is the most common way producers control weeds.

7. A little more than three-quarters of the producers test their soil at some point.

8. Less than one-quarter of producers who fertilize follow the soil test recommendation.

9. West Virginia beef producers most commonly extending the grazing season by grazing on the aftermath of first cut hayland during the summer slump and stockpile forage for winter.

10. Grass is the most commonly used buffer zone of those beef producers who have buffer zones on their farm.

11. The biggest barrier to rotational grazing for beef producers is providing water to their livestock.

\section{Recommendations}

Based on the results obtained from the study, the following recommendations are offered:

1. Results of this study should be made available to West Virginia County Extension Educators, West Virginia University researchers and Extension Specialists, and the West Virginia Conservation Agency. 
2. Educators should distribute or make available information on orchardgrass and white clover to maximize knowledge and production of these two species. Also, educators should encourage farmers to expand and use other various grasses (ex. tall fescue) and legumes and provide educational programs detailing the benefits, uses, and management of these species.

3. Educators and agencies should develop, focus, or implement programs on importance of water quality; at the same time provide workshops on how to cost effectively distribute water to fields without relying on direct access to streams and creeks. This effort also has an opportunity to address and should focus on the biggest barrier to rotational grazing, "providing water to livestock," as to increase the practice rate.

4. Future research should focus on why other methods for extending the grazing season are not readily acceptable to producers and develop a list of factors to assure producers of the economic profitability of implementing these practices.

5. Educators and agencies should reiterate the importance of soil testing, encourage participation, and increase program awareness. At the same time, educators and agencies should help clients to understand the soil test report, how to take a soil sample correctly, and provide information on soil type.

6. Grazing best management practices should be developed and made accessible for West Virginia beef producers.

7. Based on producers' comments from the survey and comments from the review committee, improvements should be made to the survey if the study were to be repeated. The improvements should include: terrain (pastures separated by rivers and/or woodland), availability of shade, condition of field(s) (ex: high weed concentration), and topography (slopes) added to the barriers to rotational grazing section; cistern added as a water source to question \#23; and add questions or 
section to the survey asking about total acreage of the farm and the total number of head (cattle) on the farm. 


\section{REFERENCES}

Ary, D., Jacobs, C. L., \& Sorenson, C. (2010). Introduction to research in education (8th ed.). Belmont, CA: Wadsworth.

Bailey, M. R., \& Merrigan, K. A. (2010). Rating sustainability: An opinion survey of national conservation practices funded through the Environmental Quality Incentives Program. Journal of Soil and Water Conservation, 65(1), 21 A-25A. Retrieved March 31, 2014, from http://www.jswconline.org.www.libproxy.wvu.edu/content/65/1/21A

Ball, D. M., Ballard, E. N., Kennedy, M. L., Lacefield, G. D., \& Undersander, D. J. (2007). Extending grazing and reducing stored feed needs. Bryan: Initiative Publication.

Ball, D. M., Hoveland, C. S., \& Lacefield, G. D. (2007). Southern forages. Norcross: International Plant Nutrition Institute.

Brown, L., Boone, K., Nokes, S., \& Ward, A. (2014). Ohio State University Extension fact sheet. Retrieved April 06, 2014, from The Ohio State University: http://ohioline.osu.edu/aex-fact/0464.html

Dillman, D. A. (2007). Mail and Internet surveys: The tailored design method (2nd ed.). New Jersey: John Wiley.

Farrington, J., \& Kuhlman, T. (2010). What is sustainability? Sustainability, 2, 34363448. Retrieved from http://www.mdpi.com/journal/sustainability 
Franzluebbers, A. J., Paine, L. K., Winsten, J. R., Krome, M., Sanderson, M. A., Ogles, K., \& Thompson, D. (2012). Well-managed grazing systems: A forgotten hero of conservation . Journal of Soil and Water Conservation Society, 100a-104a.

Retrieved April 27, 2014, from

http://county.wsu.edu/kittitas/Documents/Grazing\%20for\%20global\%20health\%2 0SWCS\%20article\%202012.pdf

History of Sustainability (2014). Retrieved March 02, 2014, from U.S. Environmental Proctection Agency: http://yosemite.epa.gov/r10/oi.nsf/Sustainability/History

Iowa Cattle Grazing Survey (2007). Cows and plows. Iowa State University Extension Service. Retrieved 05 2013, from http://www.iowabeefcenter.org/Cows_Plows/Iowa\%20Cattle\%20Grazing\%20Sur vey\%20(section\%201).pdf

Krejcie, R. V., \& Morgan, D. W. (1960). Determining sample size for research activiites. Educational and Psychological Measurement(30), 607-610.

Krueger, W. C., Sanderson, M. A., Cropper, J. B., Kelley, C. E., Pepper, R. D., Shaver, P. L., \& Miller-Goodman, M. (2002). Environmental impacts of livestock on U.S. grazing lands. Ames, Iowa. Retrieved February 16, 2014, from Cast-science.org: http://www.castscience.org/publications/?environmental_impacts_of_livestock_on_us_grazing_la nds\&show=product\&productID $=2898$

Merrill, J. (2006). The Future of Managed Grazing: Barriers to managed grazing in Wisconsin and how to overcome them. Michael Fileds Agricultural Institute. Troy, Wisconsin. Retrieved April 26, 2014, from http://www.cias.wisc.edu/wpcontent/uploads/2006/08/mfai-grazing.pdf 
NRCS (2014). Environmental quality incentives program. Retrieved March 31, 2014, from USDA NRCS:

http://www.nrcs.usda.gov/wps/portal/nrcs/main/national/programs/financial/eqip/

Paine, L., \& Glidersleeve, R. (2011). A summary of beef grazing practices in Wisconsin. Retrieved April 13, 2014, from University of Wisconsin Extension Service: http://fyi.uwex.edu/grazres/files/2011/05/2011-Beef-Grazing-SummaryFINAL.pdf

Rayburn, E. B., Murphy, B., Clark, E. A., Benson, G. A., Drelich, J., Emmick, D. L., . . . Vough, L. R. (2006). Managing and marketing for pastured-based livestock production. New York: Natural Resource, Agriculutre, and Engineering Service.

Robinson, J., Shaver, P., Wrightman, L. (1991). Measures of personality and social psychological attitudes. (pp 1-16) New York: Academic Press.

Shreck, A., Feenstra, G., \& Getz, C. (2006). Social sustainability, farm labor, and organic agriculture: Findings from an exploratory analysis. Agriculture and Human Values, 23(4), 439-449. Retrieved March 13, 2014, from http://dx.doi.org.www.libproxy.wvu.edu/10.1007/s10460-006-9016-2

Sustainability - Basic Information (2014). Retrieved March 02, 2014, from U.S. Environmental Proctection Agency: http://www.epa.gov/sustainability/basicinfo.htm

Sustainability (2014). Webster-Dictionary.org. Retrieved March 02, 2014, from http://www.webster-dictionary.org/definition/sustainability

The Maryland Grazers' Network (2011). Retrieved April 27, 2014, from Universtiy of Maryland Center for Enviornmental Science: http://www.umces.edu/sites/default/files/pdfs/cbfn_MDGrazers.pdf 
Tilman, D., Cassman, K. G., Matson, P. A., Naylor, R., \& Polasky, S. (2002).

Agricultural sustainability and intensive production practices. Nature, 418, 671677. Retrieved March 16, 2014, from http://www.nature.com/nature/journal/v418/n6898/full/nature01014.html

United Nations (1987). Report of the World Commission on Environment and Development: Our Common Future. Retrieved March 02, 2014, from United Nation: http://conspect.nl/pdf/Our_Common_FutureBrundtland_Report_1987.pdf

United States Department of Agriculture (2012). Census of Agriculture. Retrieved April 20,2014 , from http://www.agcensus.usda.gov/Publications/2012/Full_Report/Volume_1,_Chapte r_1_State_Level/West_Virginia/st54_1_014_016.pdf

Watershed Resource Center (n.d.). WV Best Management Practices of Conservation Practice Standards. Retrieved April 19, 2014, from: http://www.wvca.us/news/upload/wvwrc_publications/2299.Ag\%20BMP\%20Ma nual\%20Revised.pdf

West Virginia Department of Agriculture (2011). West Virginia Conservation Agency Annual Report Retrieved April 20, 2014, from: http://www.wvagriculture.org/images/Executive/Annual/11AR-WVCA.pdf

Winrock Internatioanl (n.d.). Rotational Grazing in the Northeast USA. Retrieved April 27, 2014, from University of Vermont: http://www.uvm.edu/ grazing/pdf_files/resources/farmer\%20survey/FINAL\%20 Survey_Results.pdf 
APPENDICES 
APPENDIX A

First Mailing Cover Letter 
March 7, 2014

Dear West Virginia Beef Producer:

As a beef producer in West Virginia, you are aware of all the components it takes to make a beef operation successful. We are asking for your assistance in determining current pasture grazing management practices and barriers to pasture grazing in West Virginia. You have been randomly selected from West Virginia's beef producers for participation in this research. You must be 18 years of age or older to participate.

My name is Marcus McCartney, a graduate student in Agricultural and Extension Education at West Virginia University. Under the direction of my advisor, Dr. Deborah Boone, I am conducting a research study to determine current grazing practices and barriers to pasture grazing in West Virginia. This study will be used to develop programs and educational materials to better serve beef producers in West Virginia. The results of this study will be used to prepare a thesis to partially fulfill the requirements for a Master of Science degree in Agricultural and Extension Education.

Your participation in this research study is completely voluntary and all information you provide will be held as confidential as possible. The survey should take about 15 minutes of your time. You may skip any question you do not feel comfortable answering and may stop at any point and submit a partially completed survey. You will notice a number at the top left-hand side of the return envelope. This number will be used to identify non-respondents for follow-up mailings and will be destroyed before the data are analyzed. The results of this survey will be reported in a summary format and individual responses will be not be identifiable.

The Institutional Review Board (IRB) at West Virginia University has approved this study and the acknowledgement of this research is on file. If you have questions or concerns about completing the survey or participating in the study, please contact Dr. Deborah Boone at 304-293-5450 or via email at Debby.Boone@mail.wvu.edu.

Please place the completed questionnaire in the self-addressed pre-paid envelope provided and drop it into the mailbox by March 28, 2014. Thank you in advance for your participation in this study, we sincerely appreciate your time and assistance.

Sincerely,

Marcus McCartney

Graduate Student
Deborah A. Boone, Ph.D.

Associate Professor 


\section{APPENDIX B}

\section{Second Mailing Cover Letter}


April 2, 2014

Dear West Virginia Beef Producer:

Recently you were sent a questionnaire about pasture grazing management practices. Your input is imperative to the success of this study. We hope you will take a few minutes to complete the survey.

As a beef producer in West Virginia, you are aware of all the components it takes to make a beef operation successful. We are asking for your assistance in determining current pasture grazing management practices and barriers to pasture grazing in West Virginia. You have been randomly selected from West Virginia's beef producers for participation in this research. You must be 18 years of age or older to participate.

My name is Marcus McCartney, a graduate student in Agricultural and Extension Education at West Virginia University. Under the direction of my advisor, Dr. Deborah Boone, I am conducting a research study to determine current grazing practices and barriers to pasture grazing in West Virginia. This study will be used to develop programs and educational materials to better serve beef producers in West Virginia. The results of this study will be used to prepare a thesis to partially fulfill the requirements for a Master of Science degree in Agricultural and Extension Education.

Your participation in this research study is completely voluntary and all information you provide will be held as confidential as possible. The survey should take about 15 minutes of your time. You may skip any question you do not feel comfortable answering and may stop at any point and submit a partially completed survey. You will notice a number at the top left-hand side of the return envelope. This number will be used to identify nonrespondents for follow-up mailings and will be destroyed before the data are analyzed. The results of this survey will be reported in a summary format and individual responses will be not be identifiable.

The Institutional Review Board (IRB) at West Virginia University has approved this study and the acknowledgement of this research is on file. If you have questions or concerns about completing the survey or participating in the study, please contact Dr. Deborah Boone at 304-293-5450 or via email at Debby.Boone@mail.wvu.edu.

Please place the completed questionnaire in the self-addressed pre-paid envelope provided and drop it into the mailbox by April 18, 2014. Thank you in advance for your participation in this study, we sincerely appreciate your time and assistance.

Sincerely,

Marcus McCartney

Graduate Student
Deborah A. Boone, Ph.D.

Associate Professor 
APPENDIX C

Questionnaire 


\section{Current Grazing Management Practices among}

\section{West Virginia Beef Producers}

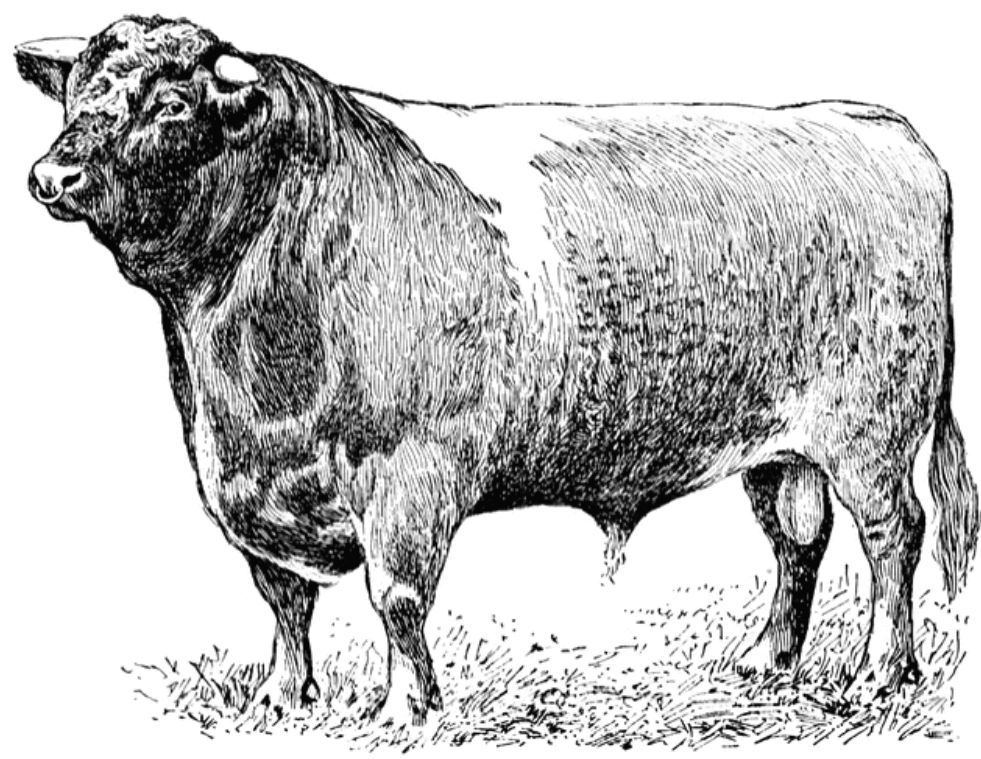

\section{Marcus Todd McCartney}

Graduate Student

Agricultural and Extension Education

Davis College of Agriculture, Natural Resource, and Design

West Virginia University

Morgantown, WV 26506 


\section{Current Grazing Management Practices among West Virginia Beef Producers}

\section{Farm Characteristics and Management}

Instructions: Please answer the following questions to the best of your ability. Each question should only have one answer. If your answer is "other" provide a brief description or response

1. In which county is your farm located? (Please list on the line below)

2. How long is the typical grazing season on your farm? (Check one)

a. Less than 5 months

b. 5-6 months

c. 7-8 months

d. Greater than 8 months

3. Which of the following describes the type of grazing system on your farm? (Check one)

a. Continuous Grazing - 1 pasture

b. 2-4 Fields - Rotational Grazing

c. 5-7 Fields - Rotational Grazing

d. 8+ Fields - Rotational Grazing

e. Strip Grazing

f.

Other 
4. How would you classify your beef operation? (Check one)
a. Cow - Calf
b. Stocker, backgrounder, grower
c. Feedlot
d. Mixed - Cow-calf and Stocker
e. Other

5. How frequently do you have your pasture's soil tested? (Check one)
a. Every year
b. Once every two years
c. Once every three years
d. Once every four or more years
e. Do not test soil

6. How frequently do you add fertilizer to the pasture's soil? (Check one)
a. Every year
b. Once every two years
c. Once every three years
d. Once every four or more years
e. As designated/recommended by the soil test
f. Do not use fertilizer

7. How frequently do you lime the pasture's soil? (Check one)
a. Every year
b. Once every two years
c. Once every three years
d. Once every four or more years
e. As designated/recommended by the soil test
f. Do not lime pasture(s) 
Record the number of acres for questions 8-12.

8. Approximately how many acres are used for grazing on your farm? acres

9. How many acres of hayland do you have on your farm? acres

10. How many acres of hayland are used for grazing after 1st cut? acres

11. How many acres of corn do you grow on your farm? acres

12. How many acres of corn-stock/stover are used for grazing? acres

\section{Stocking Rates}

13. How many calves do you sell in the fall on your farm?

14. How many calves do you keep over winter?

15. How many over winter calves do you sell in the spring on your farm?

16. How many stocker cattle do you buy in the fall on your farm?

17. How many stocker cattle do you buy in the spring on your farm? 


\section{Pasture Plant Composition}

18. How important are each of the following grass species in your farm's forage grazing system? (Please indicate the importance of each species by circling a response where $0=$ no importance to $10=$ extremely important).

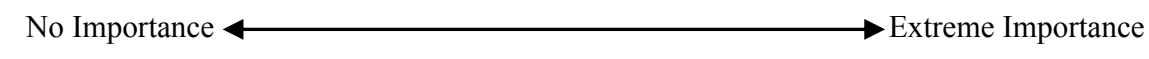

$\begin{array}{lccccccccccc}\text { a. Bermuda Grass } & 0 & 1 & 2 & 3 & 4 & 5 & 6 & 7 & 8 & 9 & 10 \\ \begin{array}{l}\text { b. Kentucky } \\ \text { Bluegrass }\end{array} & 0 & 1 & 2 & 3 & 4 & 5 & 6 & 7 & 8 & 9 & 10 \\ \begin{array}{l}\text { c. Orchard Grass } \\ \text { d. Perennial Rye }\end{array} & 0 & 1 & 2 & 3 & 4 & 5 & 6 & 7 & 8 & 9 & 10 \\ \begin{array}{l}\text { Grass } \\ \text { e. Tall Fescue }\end{array} & 0 & 1 & 2 & 3 & 4 & 5 & 6 & 7 & 8 & 9 & 10 \\ \text { f. Timothy } & 0 & 1 & 2 & 3 & 4 & 5 & 6 & 7 & 8 & 9 & 10 \\ & 0 & 1 & 2 & 3 & 4 & 5 & 6 & 7 & 8 & 9 & 10\end{array}$

19. How important are each of the following legumes in your farm's forage grazing system? (Please indicate the importance of each species by circling a response where $0=$ no importance to $10=$ extremely important).

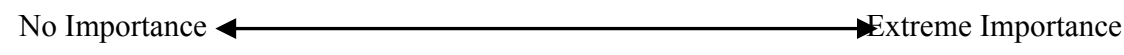
a. Alfalfa
0
2
3

4
$5 \quad 6$

7
$\begin{array}{lll}8 & 9 & 10\end{array}$
b. Birdsfoot Trefoil

$\begin{array}{lll}0 & 1 & 2\end{array}$
c. Red Clover

$\begin{array}{lll}0 & 1 & 2\end{array}$
d. White Clover

$\begin{array}{lll}0 & 1 & 2\end{array}$

3
3




\section{Extending the Grazing Season}

20. Summer slump is known as a period of time when pasture forage growth is minimal during the months of June, July, and August. With what frequency do you use the following techniques on your farm to extend grazing throughout the "summer slump" of forage production? (Please indicate the frequency each technique is used by circling a response where $0=$ not used to $10=$ used extensively).

Not Used

a. Graze on warm season perennial grass (Bluestem, Bermuda, Switchgrass, Broomsedge)

b. Graze on warmseason annual grass (Sudangrass, Sorghum, Pearlmillet, Maize/Corn)

c. Graze aftermath of hayfield

d. Sell to reduce herd number

e. No summer slump because we brush-hog excess spring forage

0

(1)

(

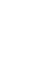

0

0

Used Extensively

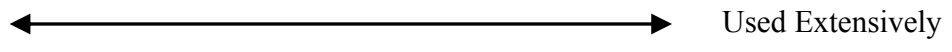

2

3

4

5

6

$7 \quad 8$

9

10

1

$\begin{array}{lllllllll}2 & 3 & 4 & 5 & 6 & 7 & 8 & 9 & 10\end{array}$

$\begin{array}{lllllllllllll}0 & 1 & 2 & 3 & 4 & 5 & 6 & 7 & 8 & 9 & 10\end{array}$

$\begin{aligned} & \text { d. Sell to reduce herd } \\ & \text { number }\end{aligned}$
$\begin{aligned} & \text { e. No summer slump } \\ & \begin{array}{l}\text { because we brush-hog } \\ \text { excess spring forage }\end{array}\end{aligned}$


21. How often do you use the following techniques on your farm to extend grazing during winter? (Please circle the frequency of each technique where $0=$ not used to $10=$ used extensively.

Not Used

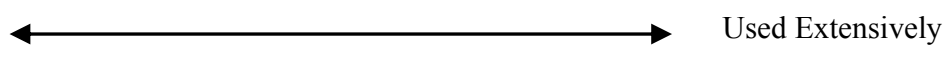

$\begin{array}{llllllllllll}\text { a. Stockpile forage } & 0 & 1 & 2 & 3 & 4 & 5 & 6 & 7 & 8 & 9 & 10\end{array}$

b. Swath - Windrow forage

$\begin{array}{lllllllllll}0 & 1 & 2 & 3 & 4 & 5 & 6 & 7 & 8 & 9 & 10\end{array}$

c. Plant winter annual grass (ex. winter rye)

$\begin{array}{lllllllllll}0 & 1 & 2 & 3 & 4 & 5 & 6 & 7 & 8 & 9 & 10\end{array}$

d. Plant brassicas (ex. kale, forage rape, turnip)

$\begin{array}{lllllllllll}0 & 1 & 2 & 3 & 4 & 5 & 6 & 7 & 8 & 9 & 0\end{array}$

e. Plant winter annual legumes (ex: hairy vetch)

$\begin{array}{lllllllllll}0 & 1 & 2 & 3 & 4 & 5 & 6 & 7 & 8 & 9 & 10\end{array}$

f. Sell to reduce herd number

$\begin{array}{lllllllllll}0 & 1 & 2 & 3 & 4 & 5 & 6 & 7 & 8 & 9 & 10\end{array}$

22. How often do you use the following techniques on your farm to extend grazing during early spring? (Please circle the frequency of each technique where $0=$ not used at all to $10=$ used extensively).

Not Used

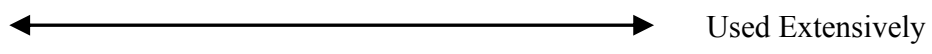

\begin{tabular}{|c|c|c|c|c|c|c|c|c|c|c|}
\hline a. Stockpile forage & 0 & 1 & 2 & 3 & 4 & 5 & 6 & 7 & 8 & 9 \\
\hline $\begin{array}{l}\text { b. Swath - Windrow } \\
\text { forage }\end{array}$ & 0 & 1 & 2 & 3 & 4 & 5 & 6 & 7 & 8 & 9 \\
\hline $\begin{array}{l}\text { c. Plant late -winter } \\
\text { annual grass (ex. winter } \\
\text { triticale) }\end{array}$ & 0 & 1 & 2 & J & 4 & 5 & 6 & 7 & 8 & 9 \\
\hline
\end{tabular}


d. Plant brassicas (kale, forage rape, turnip)

e. Plant winter annual legumes (hairy vetch)

f. Sell to reduce herd number

$\begin{array}{lllllllllll}0 & 1 & 2 & 3 & 4 & 5 & 6 & 7 & 8 & 9 & 10\end{array}$

1

$\begin{array}{lllllllllll}0 & 1 & 2 & 3 & 4 & 5 & 6 & 7 & 8 & 9 & 10\end{array}$

\section{Water}

23. How important are the following pasture water distribution systems on your farm?

(Please record the importance of each by circling a response where $0=$ no importance to $10=$ extremely important).

No Importance

Extreme Importance

a. Pond water, livestock have direct access

b. Pond water, pump into a storage vessel/tank

c. Natural Spring, livestock has direct access

d. Natural Spring, pump into a storage vessel/tank

$\begin{array}{lllllllllll}0 & 1 & 2 & 3 & 4 & 5 & 7 & 8 & 9 & 10\end{array}$

e. Stream/creek, livestock has direct access

f. Stream/creek, pumped into a storage $\quad \begin{array}{llllllllllll} & 0 & 1 & 2 & 3 & 4 & 5 & 6 & 7 & 8 & 9 & 10\end{array}$ vessel/tank 
g. Drilled-well water

directly to paddock(s)

h. City water directly

to paddock

i. Centralized water station

j. Movable water

source to each

paddock

k. Hauled to

permanent holding

source in paddock(s)

24. Buffer zones are permanent vegetative land that is used to intercept runoff and minimize soil erosion. Buffer zones are commonly used around bodies of water. How would you describe the buffer zones and natural waterways in your pastures on your farm? (Please indicate the occurrence of each by circling a response where $0=$ no occurrence to $10=$ frequently occurring).

No Occurrence

Frequently Occurring

a. Buffer Zone comprised of grass

$\begin{array}{lllllllllll}0 & 1 & 2 & 3 & 4 & 5 & 6 & 7 & 8 & 9 & 10\end{array}$

b. Buffer zone comprised of shrubs

0

c. Buffer zone comprised of trees

$\begin{array}{lllllllllll}0 & 1 & 2 & 3 & 4 & 5 & 6 & 7 & 8 & 9 & 10\end{array}$

d. No buffer zone but $\begin{array}{lllllllllllll}\text { water ways are blocked } & 0 & 1 & 2 & 3 & 4 & 5 & 6 & 7 & 8 & 9 & 10\end{array}$ by fencing

e. No buffer zone and water ways are accessible to livestock 
f. No natural water ways on the farm

123

\section{Weed Control}

25. How frequently are each of the following methods for controlling weeds is practiced on your farm?

(Please circle the frequency of each method used where $0=$ not used to $10=$ used extensively).

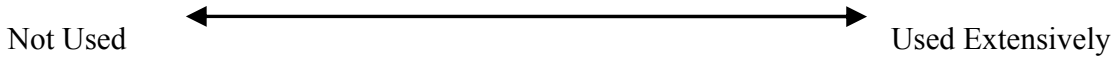
a. Herbicide control (chemicals)

$\begin{array}{lllllllllll}0 & 1 & 2 & 3 & 4 & 5 & 6 & 7 & 8 & 9 & 10\end{array}$

b. Mechanical-Physical control (hand pulling; mulching, brush hogging)

$\begin{array}{lllllllllll}0 & 1 & 2 & 3 & 4 & 5 & 6 & 7 & 8 & 9 & 10\end{array}$

c. Cultural control $(p H$, rotational grazing)

d. Biological control, Co-grazing (multispecies grazing together)

e. Biological control, different times. (multispecies grazing at different times)

$\begin{array}{llllllllllll}\text { f. Do not control weeds } & 0 & 1 & 2 & 3 & 4 & 5 & 6 & 7 & 8 & 9 & 10\end{array}$ 


\section{Barriers to Rotational Grazing}

Instructions: Use the following scale to indicate your choice by circling the letters that best corresponds to your response. SA-Strongly Agree, A - Agree, D - Disagree, SD Strongly Disagree, or NA - Not Applicable.

26. Which of the following do you see as barriers to rotational grazing on your farm?

\begin{tabular}{|c|c|c|c|c|c|}
\hline Barriers to Rotational Grazing & 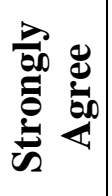 & & 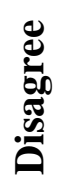 & 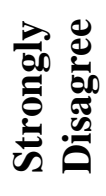 & 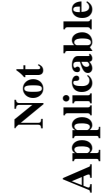 \\
\hline a. Not enough land/pastures & SA & A & $\mathrm{D}$ & SD & NA \\
\hline b. Cost of fencing & SA & A & $\mathrm{D}$ & SD & NA \\
\hline c. Increase in labor & SA & A & $\mathrm{D}$ & SD & NA \\
\hline d. Increase in time & SA & A & $\mathrm{D}$ & $\mathrm{SD}$ & NA \\
\hline e. Availability of forage & SA & A & $\mathrm{D}$ & $\mathrm{SD}$ & NA \\
\hline f. Predicting or determining forage availability & SA & A & $\mathrm{D}$ & $\mathrm{SD}$ & NA \\
\hline g. Determining the Stocking Rate & SA & A & $\mathrm{D}$ & $\mathrm{SD}$ & NA \\
\hline h. Providing water to the livestock & SA & A & $\mathrm{D}$ & SD & NA \\
\hline $\begin{array}{l}\text { i. Knowing which grass and legume species that are } \\
\text { grazing tolerant }\end{array}$ & SA & A & $\mathrm{D}$ & SD & NA \\
\hline j. Lack of information on pasture management & SA & A & $\mathrm{D}$ & $\mathrm{SD}$ & NA \\
\hline k. Skepticism from other farmers & SA & A & $\mathrm{D}$ & SD & NA \\
\hline 1. Skepticism from family members & SA & A & $\mathrm{D}$ & SD & NA \\
\hline m. Animal Performance & SA & A & $\mathrm{D}$ & SD & NA \\
\hline
\end{tabular}




\section{Demographics}

27. Would you consider yourself to be a full-time or part-time beef producer? (Check one)
a. Full-time
b. Part-time

28. What is your employment status outside of farming? (Check one)
a. Hold full-time job off farm
b. Hold part-time job off farm
c. Retired
d. Do not have off farm employment

29. What is your age? (Check one)
a. 30 years and below
b. $31-40$ years
c. $41-50$ years
d. $51-60$ years
e. $61-70$ years
f. Over 70 years

30. What is your highest level of education? (Check one)
a. Did not graduate high school
b. High School diploma or equivalent
c. Some college
d. Two - year college degree
e. Four - year college degree
f. Graduate degree (Master's, PhD) 
Comments (regarding questionnaire): 
--END SUVREY-

Thank you for taking the time to complete this questionnaire!

*Please take a minute to review the survey to verify there are no unanswered questions.

If you have any questions regarding the questionnaire, please contact me or my advisor at:

Marcus McCartney: mmccart2@mix.wvu.edu

Dr. Deborah Boone: debby.boone@mail.wvu.edu

Phone: (304) 293-5450 


\section{APPENDIX D}

Beef Producer Comments from End of Survey 


\section{Comments from Survey}

Lime hard to get

My farm is small. I have city water and West Fork River as a barrier along my farm. We buy 5-8 head in late March or early April and butcher in mid to late Oct. I put my cattle on grain, sweet feed and 16\% corn meal also mixed with old bread from our local bakery.

It is too hard to grow legumes or stockpile grass of deer

I operate totally on rented land therefore it is hard for me to use many of the grazing practices that would increase production.

Tall fescue-I hate it!

I am considering multispecies in my operation. Looking for data

WVU extension programs available. Relationship of grass production, quality and animal performance.

Sorry for not completing this survey but our beef enterprise is for home consumption only, not commercial

Biggest problem with weeds in pastures and hayfields are milk weed, dog bane hemp, horse nettle, Japanese knot weed. We have sprayed but have had limited success. We have reduced herd size to 35 head.

Some questions could not be answered with the answer scheme. For example, choices in question 23, I would answer not used than no importance. It would be well to find out why some of us do not practice rotational grazing. If we would be willing to try rotational grazing, what type of assistance if any would we need to set up a rotational grazing 
system? Regarding question 26, there are more barriers than what are listed such as terrain, rivers, streams, woodlands, ect.

Good luck, keep up the good work.

One of the largest and often overlooked barriers to pasture management in WV is the terrain of the land. Much of the pasture on our farm is hillside which will not allow brush hogging or lime/fertilizer application.

I had a registered Angus and now retired and sold farm

I'm fourth generation small farmer, since my retirement from public works I've been able to attend the Western Conservation District seminars at Pt. Pleasant, WV. Those meetings are very informational and helpful. We are using this information to improve our management of the hay, pasture, water and cattle.

Check with USDA NASS. They ask many farmers many of these questions regularly

I run cattle on leased land is the main reason I don't rotational graze. I rotationally graze the property I own. I run sheep and goats on the land I own.

Much of property is leased from others. I am cautious of improvements and investments in property owned by someone else. Improvements/investments in property I own is much more substantial.

The three biggest hindersome to grazing are fence placement, getting water where you need it and supplying information in farmer english, a simplified way of explaining animal unit/day, not several different options that just cloud the issue.

Have been rotation grazing for years. Just need 2-3 more paddocks but have been able to get by. I have a farm up the road to get by in a real dry season. 
Too long worry about how important this data will be in meeting your research West Virginia slopes and hills make it difficult to practice rotational grazing and it is almost impossible to apply lime and fertilizer to many of the pastures.

Availability of shade is a barrier to rotational grazing. 
VITA

Marcus McCartney

Education:

Professional

Experience:
May 2003

December 2014

July 2014 - current

January 2013 - June 2013

August 2012 - December 2012

August 2011 - May 2012
Bachelors of Science

Business Management

West Virginia University

Morgantown, West Virginia

Masters of Science

Agricultural and Extension

Education

West Virginia University

Morgantown, West Virginia

Agricultural and Natural Resources

Extension Educator

OSU Extension Service

The Ohio State University

Pomeroy, Ohio

Graduate Assistant

Energy Express

WVU Extension Service

West Virginia University

Morgantown, West Virginia

Graduate Research Assistant Soil Science and Agronomy

Department

West Virginia University

Morgantown, West Virginia

Graduate Teaching Assistant

Agricultural and Extension

Education Department

West Virginia University

Morgantown, West Virginia 